
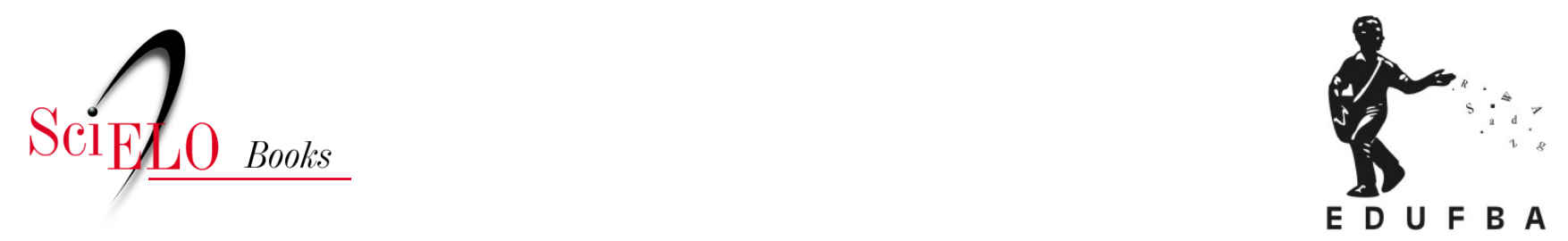

\title{
"Fumam a planta e dela sabem mil coisas" uso coletivo de maconha e os significados presentes na fumaça
}

\author{
Jorge Emanuel Luz de Souza
}

\section{SciELO Books / SciELO Livros / SciELO Libros}

SOUZA, J.E.L.S. "Fumam a planta e dela sabem mil coisas": uso coletivo de maconha e os significados presentes na fumaça. In: Sonhos da diamba, controles do cotidiano: uma história da criminalização da maconha no Brasil republicano [online]. Salvador: EDUFBA: CETAD/UFBA, 2015, pp. 161-217. Drogas: clínica e cultura collection. ISBN: 978-85-232-2023-5.

https://doi.org/10.7476/9788523220235.0006.

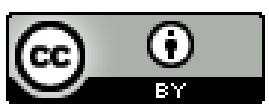

All the contents of this work, except where otherwise noted, is licensed under a Creative Commons Attribution 4.0 International license.

Todo o conteúdo deste trabalho, exceto quando houver ressalva, é publicado sob a licença Creative Commons Atribição $\underline{4.0}$. 


\section{"FUMAM A PLANTA E DELA SABEM MIL COISAS": USO COLETIVO DE MACONHA E OS SIGNIFICADOS PRESENTES NA FUMACSA}

O "caráter gregário" da maconha foi assinalado por diversos especialistas do proibicionismo, literatos e estudiosos da cultura, seja inserido num contexto religioso ou não religioso. Compreendendo os elementos que compunham o hábito de fumar maconha coletivamente e visibilizando as formas que o hábito assumia, será possivel indicar alguns significados que o preenchiam.

Para tanto, será preciso lançar mão de alguns textos importantes de sociólogos, folcloristas e especialistas brasileiros de diversas áreas que informaram o discurso de combate à maconha e a sua criminalização. Foram médicos, psiquiatras, juristas, botânicos e agrônomos que não raro também fizeram carreira política ou ocuparam importantes cargos públicos. ${ }^{22}$ Essa produção se concentra entre as décadas de 1930 e 1940, mas com exemplares também nas anteriores, como "Os fumadores de maconha: efeitos e males do vício e "Sobre o vício da diamba" e na seguinte, como "Folclore da maconha".

Heitor Peres, Pedro Pernambuco Filho, Francisco de Assis Iglésias, José Lucena, Garcia Moreno, Eleyson Cardoso, Alceu

22 O dr. Rodrigues Dória, por exemplo, foi governador de Sergipe entre 1908 e 1912 . 
Sonhos da diamba

Maynard Araújo e Mário Ypiranga Moteiro entre outros, foram muitas vezes testemunhas oculares da prática. O olhar atento e a exposição detalhada dos objetos e ritos, a busca de relações com outras partes do mundo, a curiosidade pelos significados de expressões usadas pelos "maconheiros", a investigação das finalidades de certas técnicas e a afirmação da existência de um "folclore da maconha" evidencia uma preocupação etnográfica que vai nos ajudar a entender como, por que e para que se usava maconha com fins psicoativos no Brasil, mas sob o ponto de vista de quem a usava.

Um aspecto que merece destaque são as técnicas de consumo da época. No Brasil, a maconha parece ter sido predominantemente consumida enquanto fumo, mas houve outras formas, a exemplo de preparados de bebidas com fins medicinais. Mesmo o hábito de fumá-la parece ter variado, com a erva pura ou misturada ao tabaco. Podia ser fumada de duas formas especificas: com o uso de um cachimbo ou como cigarro. Essa diferença é significativa para a compreensão das dinâmicas de cada contexto onde se deu o uso, como se verá adiante.

Houve também variações dentro dessas formas. O cigarro seria diversificado em dimensões a depender da situação de uso, podendo ser grande, como os "cigarros coletivos", enrolados em palha de milho ou papel de embrulho que serviam a todos na "roda" ou o "cigarrinho individual". É Garcia Moreno na década de 1940, em "Aspectos do maconhismo em Sergipe", um dos que jogam uma luz sobre esse ponto:

Na classificação dos fumadores, há três tipos de cigarros, feitos todos com folhas e sumidades floridas da maconha fêmea, após ligeira trituração manual [...] 'Morrão', 'baseado' e 'fininho' são os tipos de cigarro. (MORENO, 1958, p. 157 , grifo nosso)

O folclorista Mário Ypiranga Monteiro (1966, p. 291) registrou em fins da década de 1950 outros termos usados na 
região Norte: "O cigarro ou cigarrilho de maconha é mais conhecido no Amazonas pelos nomes de dirijo e tauari”. Também sobre essa técnica, nos diz Décio Parreiras em 1949:

O cigarro é confeccionado na palma da mão esquerda por uma série de movimentos semelhantes aos dos que fazem o cigarro de palha e fumo de rolo, misturando folha e inflorescência. $O$ papel que serve para o cigarro da maconha e que, na gíria, é chamado seda, tem que ser grosso, em geral de embrulho e que não tenha rápida combustão, havendo os que fumam a diamba envolta em brácteas de milho. (PARREIRAS, 1958, p. 273, grifo do autor)

Essa variação, além de atender a critérios pessoais - do gosto de cada fumante -, do ponto de vista social, evidencia a interação das técnicas de uso com as peculiaridades de cada contexto. Mais uma vez Garcia Moreno (1958, p. 157) assinala um dado significativo ao afirmar que na capital de Sergipe só era "conhecido o uso da maconha sob a forma de cigarro", ficando o uso do cachimbo circunscrito ao "baixo São Francisco". Ou seja, na capital e no interior predominavam diferentes técnicas de consumo. Uma observação do psiquiatra José Lucena (1958, p. 210) ilumina ainda mais a questão:

A preferência que se verifica no Recife pelo cigarro individual ou fumado em grupo é explicável pelo receio de perseguição policial, por motivos de comodidade, etc. Às vezes os 'maconhistas' usam a erva em ruas mais afastadas do centro da cidade [...].

Os dois especialistas perceberam diferenças na técnica de consumo em contextos sociais diferentes: no interior, onde a repressão policial ao uso de psicoativos parecia ser menos ostensiva, ${ }^{23}$ era mais comum observar-se o uso do cachimbo,

23 Alguns autores afirmam que no interior as pessoas usavam e vendiam maconha sem saber que estava criminalizada, por isso, sendo fácil encontrar nas feiras livres entre outras ervas. (FARIAS, 1958; PARREIRAS, 1958) 
enquanto que nas capitais, onde a vigilância se tornava mais visivel e o Estado organizava o espaço para facilitar seu desempenho, predominavam os cigarros. Pode-se arriscar, por motivos evidentes, que em caso de repressão policial fosse muito mais fácil se livrar de um cigarro que de um cachimbo, pois este é mais visivel e dificil de transportar sem ser percebido pelas autoridades.

Em Salvador não foi registrada a existência de cachimbos entre os casos policiais em que houve apreensão de maconha, apenas de cigarros, como demonstram as fontes mencionadas até aqui. Porém, em 1958, na ocasião da inauguração do Museu Antropológico do Instituto Médico Legal da Bahia, sob a direção de Estácio de Lima, o Diário de Notícias registrou que a primeira de suas vitrines e seções era dedicada à maconha: "[...] folhas, flores, sementes, caules e raizes tenras. Vários tipos de cigarros e uma grande coleção de cachimbos, alguns exóticos, chamados pelos viciados de 'Maricas". (MUSEU, 1958, p. 12, grifo nosso)

O jornal aponta exatamente as duas técnicas de consumo registradas como predominantes pelos especialistas. Apesar de destacar que no acervo havia "uma grande coleção de cachimbos", infelizmente, não informa se esses, que chamaram à atenção também pela sua forma ("alguns exóticos”), eram provenientes da capital ou do interior, da Bahia ou de outro estado.

Nesse ponto, é interessante investigar mais um pouco o uso do cachimbo, bastante referido como "maricas" ou "marica", mas também chamado de "grogoió", "bomba" e "boi". Como dito, essa técnica de consumo foi caracterizada como típica do meio rural, do sertão, sobretudo do Nordeste, e considerada, por vezes, algo exótico, o que talvez explique a grande atenção dada a ela pelos especialistas do proibicionismo da maconha. O escritor Alberto Deodato é quem nos leva ao encontro de alguns homens a fumar: 
Néo arrumava sobre a esteira a maricas, o molhe de maconha, cuidando dos preparativos, com aquele prazer egoísta, seu, em primar como veterano no vício... E trazia aos poucos as drogas, cheirando a planta com volúpia, beijando a maricas, abraçando-a, antes de colocá-la sobre a esteira.

Olhava-a longamente, ébrio de alegria, e ia buscar outro objeto, tremendo, esfregando as mãos, satisfeito.

Inácio olhava tudo, suspenso, indiferente à ânsia e ao prazer antegozado por seus companheiros. Afinal, Néo sentou-se à cabeceira.

A luz macerava as caras rústicas dos degenerados, afundando-lhes os olhos, pondo-lhes em relevo a ossatura.

Néo, com os beiços arregaçados, exibindo as gengivas roxas, os braços cruzados beaticamente nos peitos, os olhos quebrados, regougou, sonambulamente:

- Maricas, minha maricas, Maricas do Néocangonha:

Eu morro de boca torta

De tanto chupar maconha.

Os companheiros the responderam, com religiosidade, de braços cruzados e o busto rodando miúdo sobre o assento:

- É de Congo

Saraminhongo...

- É de Congo

Saraminhongo...

Néo chupou longamente o canudo da maricas, cuja água aquecida filtrava o fumo da maconha. Saboreou estrábico o narcótico e, dentro de um novelo de fumaça, gaguejou:

- Maconha é bicho danado,

Bicho danado é maconha;

De tanto bem à maricas

A gente perde a vergonha... 
Quando foi a vez de Inácio, o iniciado olhou-a longamente com a tristeza infinita de sua mágoa... Como os seus companheiros, chupou, sôfrego, o gargalo. Careteou estremecendo, repugnando. Néo, porém, desassisado, babujou cabisbaixo um pedaço da quadra:

- Lá vai s'embora a fumaça

Da minha maconha, Chico...

E os versos rarearam... O estribilho morreu na boca dos narcotizados.

(DEODATO, 1922 apud BOTELHO; PERNAMBUCO, 1958, p. 25-26)

Esta narrativa, que o jurista sergipano apresenta em um dos contos do livro Canaviais, publicado no início dos anos 1920, possui termos oriundos da medicina social e das suas reflexões sobre as "toxicomanias" tais como "vício", "degenerados" e "narcótico". Fazia poucos anos da publicação de "Os fumadores de maconha: efeitos e males do vício", do dr. Rodrigues Dória, considerado fundador da campanha contra a maconha no Brasil, em 1915.

Pelo visto o escritor estava atualizado em relação ao discurso condenatório que se construía.

O conto narra, nessa passagem, reunião onde se percebe uma prática ritualizada: o emprego da "maricas" para fumar e um lugar de destaque para o objeto na prática; os procedimentos são realizados por um "veterano", ou seja, alguém de status elevado entre os presentes, que, por sinal, sentava à cabeceira da roda; há preparativos, objetos e elementos para consumo são dispostos numa esteira; há uma série de comportamentos de exaltação da erva e da "maricas"; são proferidos versos que remetem ao uso da maconha, onde um se pronuncia primeiro e os demais presentes respondem em coro; há ainda o caráter de iniciação da reunião, com um dos presentes experimentando pela primeira vez. 
Além disso, há os termos "Congo" e "cangonha": o primeiro é o nome de um importante reino africano situado na região centro-ocidental do continente, enquanto que o segundo é uma adaptação linguística para a palavra kangonha, um dos termos da lingua kimbundo que designa a própria erva na África central. Esse dado será discutido um pouco mais adiante.

O cachimbo poderia ser de madeira, argila, chifre, cerâmica e até de pedra, todavia o material mais usado parece ter sido a cabaça e, segundo Heitor Peres (1958, p. 69), volteava a roda dos presentes "à maneira do chimarrão gaúcho". F. de Assis Iglésias faz uma descrição detalhada do objeto, feito de cabaça, e do seu funcionamento:

Há uma cabaceira que produz uma pequena cabaça, da capacidade mais ou menos de um litro, cuja forma se presta muito para transformá-la num cachimbo. Tem um corpo quase esférico, havendo um estrangulamento para o lado em que se fixa o pedúnculo que corresponde ao canudo do cachimbo.

No pólo da parte esférica abre-se um buraco do diâmetro de alguns centímetros onde se adapta uma panelinha de barro em forma de cone truncado com a base para cima, por onde se introduz a diamba; no fundo há um buraco. $\mathrm{Na}$ extremidade, onde há o sinal do pedúnculo, abre-se um pequeno orifício. A cabaça é cheia de água até encontrar o cano da panelinha em que está a diamba. Põe-se uma brasa na panelinha cheia de diamba e chupa-se pelo orifício. A fumaça atravessa a água e vai á boca do fumante. (IGLÉSIAS, 1958, p. 18)

O agrônomo explora com afinco a estrutura da "maricas", parecendo mesmo que presenciou a confecção do objeto. Apresenta-nos um equipamento feito com uma cabaça na qual são acoplados outros elementos para transformá-la num cachimbo destinado ao uso da maconha. Possui certa singularidade ao servir como recipiente para uma porção de água por onde a 
Sonhos da diamba

fumaça passa antes de ser inalada. É possivel ver nas figuras abaixo alguns modelos de "maricas" utilizados nas regiões Norte e Nordeste.

Figura 9 - Maricas

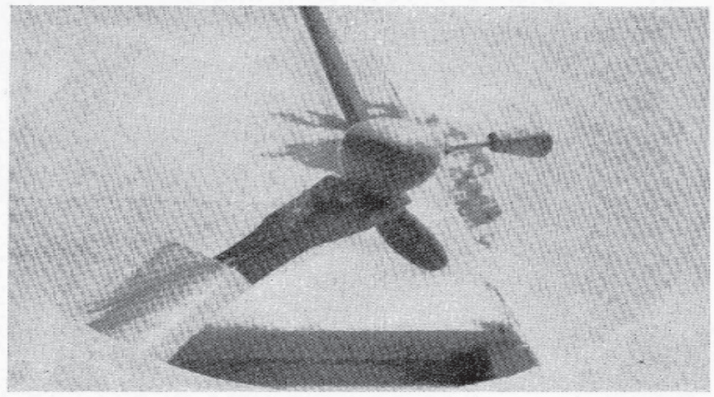

Fonte: Iglésias (1958).

Figura 10 - Diferentes tipos de Maricas

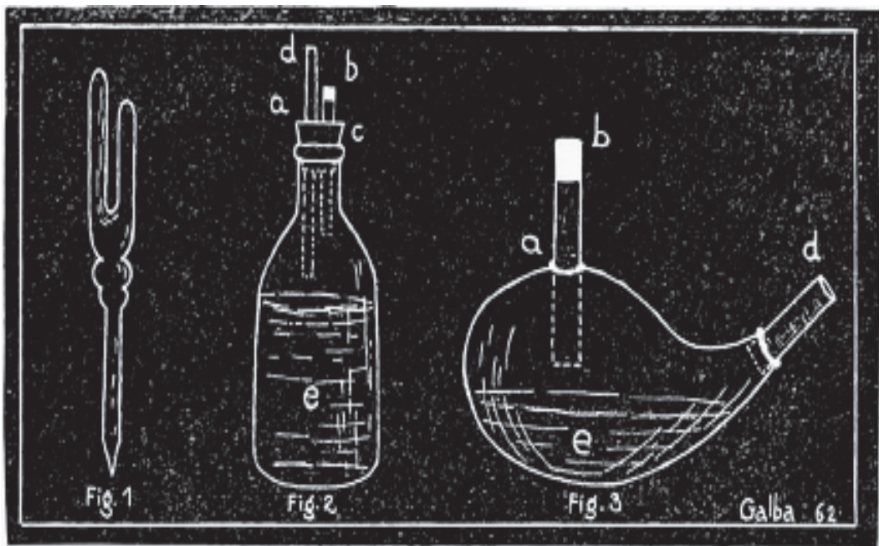

Fonte: Carlini (2006, p. 316).

Parreiras, por exemplo, comenta que

[...] na técnica de sua confecção, entra[va] muito do gosto artístico de seus donos, desde a simples garrafa comum, 
ao chifre de boi e aos frutos de cucurbitáceas [cabaças] [...] com ou sem figuras e desenhos.Vimos um desses maricas, cujo fornilho representa a cabeça de um homem, sem a calote craniana e sem cérebro, e que pertenceu a um fumador de maconha de 82 anos. (1958, p. 274)

Pelas palavras de Parreiras percebe-se mais uma vez a ritualização do consumo da maconha nesses contextos. Sua descrição coincide com a observação feita por outro especialista sobre a maconha no Brasil, Heitor Peres (1958, p. 68), para quem os cachimbos podiam ser "toscos ou aperfeiçoados". Isso evidencia outro tipo de usuário, distante daquele modelo que a campanha proibicionista visava consolidar. Percebe-se que o consumo, nesses contextos, congregava valores e práticas que lhe conferiam um caráter regulado, capaz de conviver com a vida cotidiana de um homem até seus 82 anos. Foram esses aspectos que a criminalização se esforçou por deslegitimar, homogeneizando as formas de relacionamento com a droga como se o seu consumo levasse a um desequilíbrio inevitável.

Figura 11 - Fornilho de "maricas"

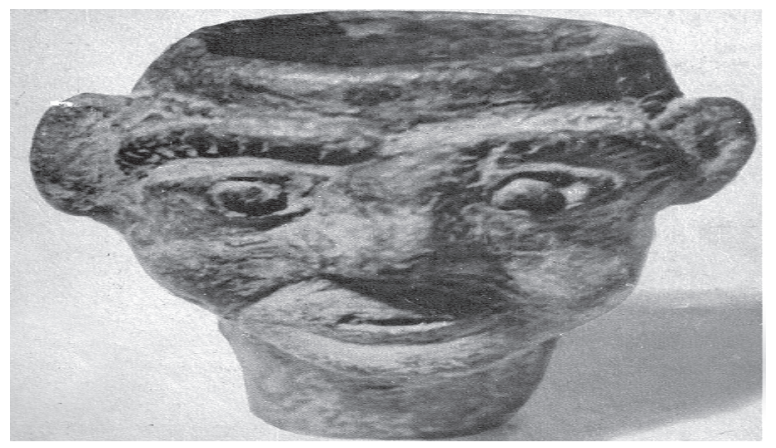

Fonte: Carlini ( 2006, p. 316).

A imagem acima representa o modelo sui generis de "maricas" descrito pelo dr. Parreiras: uma cabeça humana assume 
o lugar do fornilho e o lugar do cérebro é ocupado pela erva, ou seja, ela está dentro da cabeça, no seu centro de comando. Nessa estetização do consumo é possivel identificar uma intenção de demonstrar individualidade, os traços esculpidos revelam um objeto que deveria ser exclusivo, único e provavelmente construído pelo próprio usuário. É também um objeto que pode nos dizer algo sobre as concepções que esses usuários possuíam acerca da alteração dos seus estados de consciência.

Não há muitas informações sobre esse aspecto da cultura material do uso da maconha no Brasil, mas é possivel extrair algumas interpretações com base em descrições de estudiosos que convergem em certos elementos. A "maricas" podia apresentar diversos adornos que variavam conforme o indivíduo que a confeccionasse; esse, pelo visto, poderia ser o mesmo dono do objeto, no qual imprime sua especificidade, seu "gosto artístico"; as matérias-primas utilizadas para a sua confecção - chifres de boi, cabaças, etc - podem apresentar também informações acerca da paisagem na qual eram produzidas; e, por fim, a longevidade da relação do dono com o objeto pode indicar que este tivesse um lugar específico na cultura que compartilhava. Os especialistas reconheciam que a "maricas" era mais que um objeto utilitário. Esses elementos permitem deduzir que o cachimbo era um objeto importante dentro de um determinado contexto social de uso da maconha.

Outros estudiosos da questão estabeleceram conexões da técnica no Brasil com outras partes do mundo. Para alguns a "maricas" era inegavelmente uma técnica africana, para outros uma imitação do narguilé oriental, e ainda havia os que encontravam semelhanças em outras culturas no continente americano. O uso de cachimbos para fumar é difundido em todo o mundo e estes objetos são empregados em ocasiões diversas, em variados rituais, assim como usados de forma coletiva ou 
individual. Fabricados em serie ou manufaturados de maneira exclusiva, vendidos ou herdados, podem ser considerados objetos sagrados em algumas culturas. (LOMBARDO, 2006) No Brasil já foram encontrados cachimbos feitos de cerâmica em sítios arqueológicos na região do São Francisco e na bacia Amazônica, datados de tempos pré-históricos ou mais recentes entre culturas indígenas, tendo uso também difundido entre africanos e afro-brasileiros durante o período colonial e imperial.

Tais cachimbos parecem ter sido usados para fumar a maconha também. Apesar de tal conclusão carecer de maiores referências - a exemplo de relatos de observadores contemporâneos - e estudos mais aprofundados, descobertas arqueológicas recentes lançaram uma luz sobre tal aspecto. Escavações para ampliação do porto e construção do pólo petroquímico do Rio de Janeiro no recôncavo da Baía da Guanabara revelaram uma grande diversidade de vestígios da cultura material dos escravos no Brasil, principalmente do século XIX. Entre estes vestígios, destacam-se os cachimbos feitos de diferentes materiais, como madeira, barro e até cerâmica, adornados com formas e estilos que remetem a etnias e regiões africanas. (CALZA et al., 2013) Cachimbos similares também foram encontrados em escavações realizadas pelo Instituto do Patrimônio Histórico e Artístico Nacional (IPHAN) e pelo Programa Monumenta, do Ministério da Cultura, no centro histórico de Salvador em 2006. (NAJJAR, 2010) Se estes encontrados em Salvador não tiveram, até o momento, divulgados resultados de análises químicas para descobrir o fumo que era carburado nos fornilhos decorados, os cachimbos encontrados no Rio de Janeiro passaram por investigações preliminares de microvestígios e indicaram a presença de maconha. (PELLI, 2010; GASPAR, 2011 apud GRANDELLE, 2011) 
Figura 12 - Fragmentos de cachimbos encontrados no recôncavo da Guanabara

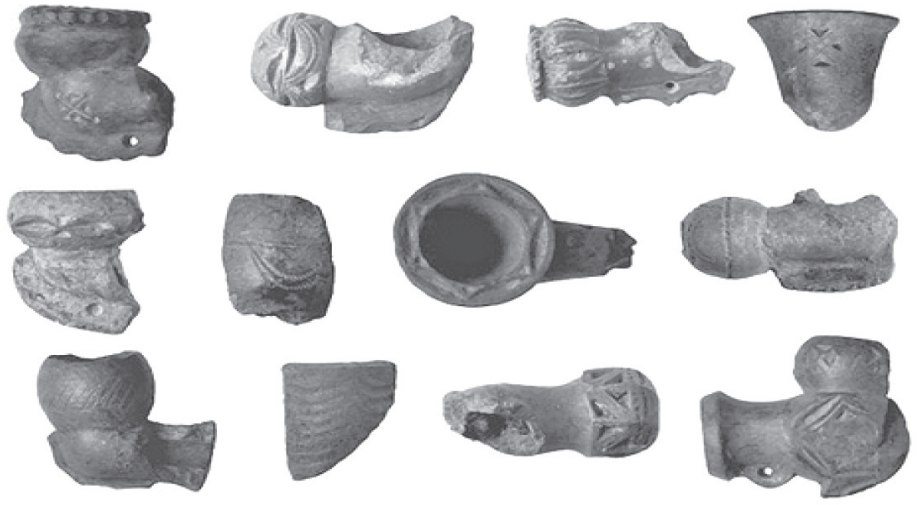

Fonte: Calza et al. (2013, p. 629).

Para Oscar Barbosa (1958, p. 36), um desses observadores do uso da maconha, na região Nordeste se preferia "o cachimbo para fumar a diamba, à moda dos pretos africanos". Como foi visto, ainda variava essa distribuição geográfica da técnica na região, sendo o uso cachimbo mais registrado no interior. De fato, o uso de cachimbos entre africanos e seus descendentes parece ter sido algo marcante na sociedade brasileira, como se pode apreender das pinturas de Guilhobel, por exemplo. Esses cachimbos possuíam significados para determinados grupos sociais que não se limitavam a sua utilidade mais imediata, expressando, como muitos outros elementos da cultura material daquele contexto, concepções de identidade individual e coletiva. (AGOSTINI, 2009) Mais algumas linhas sobre o assunto podem revelar que tanto a "maricas" quanto seu emprego no consumo de maconha encerram referências diversas e também distantes, mas que remetem, sobretudo, à África.

Um dos poucos a registrar esse uso no século XIX foi o diplomata britânico Richard Burton. No Brasil entre 1865 e 
1868, Burton visitou diversos lugares do interior de Minas Gerais e compilou as suas observações em Viagens aos planaltos do Brasil. Assinalou o uso da maconha por escravos em dias festivos no século XIX: "Os preguiçosos e dissolutos iriam gozar a santidade do dia à moda africana, deitados ao sol e, se puderem, bebendo e fumando haxixe, como os semi-selvagens da Serra Leoa". (BURTON, 1976 apud SOUZA, 2004b, p. 95) Burton nos dá pistas acerca formas de consumo da maconha, mas nada disse sobre a técnica, se cigarros ou cachimbos.

Seguindo as indicações de Burton e do dr. Barbosa chega-se ao relato de dois exploradores portugueses que chefiaram uma expedição por regiões da África centro-ocidental entre 1877 e 1880. Ao alcançarem a nascente do Cambo - um afluente da bacia hidrográfica do rio Congo situado no atual território de Angola - encontraram um grupo de homens "fumando a fatal liamba":

Surpreendidos por uma medonha trovoada, seguida de chuva diluvial, conservamo-nos acampados, com grande satisfação dos nossos, que, em meio de uma nuvem de espesso fumo, enchendo completamente os fundos, passavam de boca em boca o cachimbo carregado de tabaco, muito abundante nas terras dos Bondos; substituindo-lhes pouco depois a mu-topa, em que se consome a fatal liamba (Cannabis sativa). Os fumantes sentam em derredor de um amplo braseiro, d'onde tiram com pequenas tenazes o carvão para começar a operação. O primeiro que a conduz aos lábios, depois de ter quatro ou cinco vezes aspirado o precioso fumo, estendendo os beiços e chupando sôfrego, desata num vivo acesso de tosse, o qual parece tanto mais satisfatório quanto mais próximo esteve da sufocação. O cachimbo é logo entregue ao imediato, que continua o processo e fica estatelado, roncando de modo singular. A água dentro do chifre borbulha, deixando passar as bolhas de fumo, que produzem ruido especial. Em breve um vacarme de urros nada permite ouvir-se. 
Os circunstantes, com a boca cheia de saliva, que expelem a miúdo, prosseguem na faina, rindo, falando, excitados pela ação perturbadora do cânhamo. Inspira na verdade dó ver semelhante cena. Mas como impedi-la, se para eles é isto um dos maiores deleites em que podem empregar o tempo? A princípio intentamo-lo; mas infrutífero esforço, porque, fugindo para o mato, faziam clandestinamente! (CAPELO; IVENS, 1881, p. 26-27, grifo do autor)

Além de descreverem a ocasião, a reproduziram na gravura abaixo:

Figura 13 - Grupo de pessoas consumindo maconha em Angola no século XIX

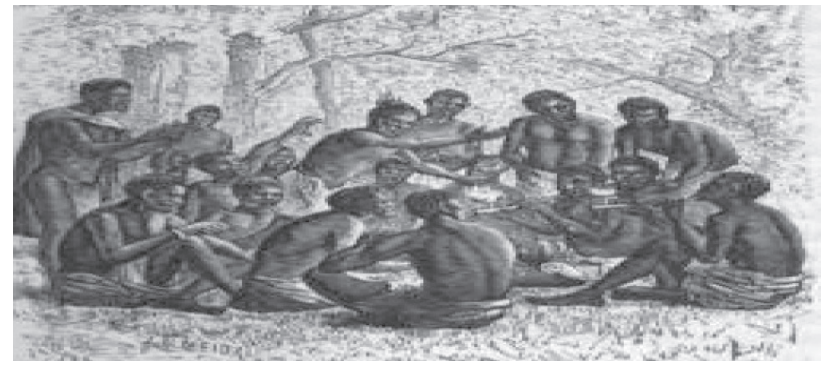

Fonte: Capelo; Ivens (1881, p. 27).

Hermenegildo Capelo e Roberto Ivens eram oficiais da Armada Real Portuguesa. A viagem, que dispensou grande atenção aos recursos hídricos de vasto território de oeste a leste do continente, resultou em "narrações, aventuras e estudos importantes" realizados ao longo de três anos. A descrição dos oficiais guarda inegáveis semelhanças com reuniões para uso coletivo da maconha no Brasil como a descrita algumas páginas antes pelo escritor Alberto Deodato.

O aspecto ritual aqui também deve ser destacado: no desenho há um grupo de homens dispostos em círculo com um deles ao centro parecendo ter proeminência sobre os demais. 
O cachimbo é feito de chifre, matéria-prima também usada no Brasil, e contém água em seu interior por onde a fumaça atravessa produzindo "ruído especial" para os fumantes. A reunião é chistosa, os presentes riem, falam excitados e "urram" animados pelo efeito alucinógeno da erva. Por fim, os oficiais evidenciam que poderia se tratar de uma prática disseminada naquela região e bastante apreciada pelos habitantes, pois seria ela "um dos maiores deleites em que podem empregar o tempo".

O relato ainda revela uma perspectiva condenatória acerca do consumo da maconha. Está claro que se trata da erva, pois os autores indicam seu nome científico, Cannabis sativa. Para eles era a "fatal liamba", expressão muito semelhante a "erva da morte", utilizada décadas depois pelo discurso da criminalização para se referir à maconha. Não por acaso consideram o estado de euforia dos fumantes na roda uma consequência direta da sua "ação perturbadora", cena que lhes "inspira dó" em presenciar.

Não contentados com o posto de meros observadores a discordar à distância, tentaram impedir aqueles homens de continuar, porém foi "infrutífero" o esforço, pois eles se afastaram para o "mato", para fumar "clandestinamente". Esse último dado revela que havia algum tipo de proibição do hábito, tornando-o "clandestino" naquele território. Estudos históricos contemporâneos sobre os usos da Cannabis no continente africano confirmam essa hipótese, demonstrando que no século XIX esses usos eram ilegais em territórios sob influência portuguesa na África. (TOIT, 1975, 1976)

A expressão mu-topa ou mutópa, utilizada para se referir ao cachimbo, significa o mesmo que tenga: "artefato de chifre ou cabaça para fumar haxixe - riamba", todas expressões da lingua kimbundo. (ASSIS JÚNIOR, p. 360, 1947) O povo citado no relato, "Bondos", ou mbundus, eram falantes de kimbundo, 
uma das linguas que fazem parte de um grande grupo linguístico conhecido, a partir de 1860, como "bantu", que se estende por grande parte do continente, sobretudo, abaixo da linha do equador.

Muitos africanos que vieram para o Brasil durante o período escravista eram provenientes de etnias que falavam línguas pertencentes a esse grupo "bantu" na África central, recriando aqui novas práticas, ritos e valores com base nos seus referenciais culturais. (SAMPAIO, 2002) Isso, no entanto, não significa que formassem um grupo homogêneo, pois, apesar das semelhanças, falavam centenas de línguas e se dividiam em reinos e sociedades que se aliavam ou se opunham. (OLIVEIRA, 1997) Ainda assim, as semelhanças linguísticas, que também denotam experiências compartilhadas, possibilitaram a comunicação e o entendimento de um lado, na travessia, e do outro do Atlântico. (SLENES, 1992)

Aqui o cachimbo recebeu diversos nomes, como foi visto, principalmente o de "maricas" ou "marica". Se esses termos não correspondem exatamente a "mutópa", as sonoridades também não são tão divergentes. Porém, mais produtivo é analisar a estrutura de ambos os objetos: a) chifre e cabaça, assim como lá, eram matérias-primas comuns para a sua confecção aqui no Brasil, como já foi visto; b) apesar de não termos uma imagem desse cachimbo usado na África, evidências linguísticas demonstram uma constituição bastante similar, pois se encontra o termo kimbundo "sâka" para se referir a uma "peça de barro que se adapta ao canudo da tenga" (ASSIS JÚNIOR, p. 354, 1947), ou seja, o fornilho no qual se coloca a erva para queimar na "maricas"; e outra característica em comum é o recipiente para água que há nos dois.

Os especialistas do proibicionismo brasileiro no século XX não estavam enganados ao traçarem paralelos entre as téc- 
nicas de consumo da maconha na África e no Brasil. Porém, utilizaram essa conexão com base numa ideologia racista, para afirmar a "inferioridade" e o "atraso" que imputavam aos seus usuários por aqui, já que constituiria, aos seus olhos, o hábito de uma "raça preta, selvagem e ignorante", bem como, para justificar a sua criminalização. (DÓRIA, 1958, p. 13)

Outra comparação feita com frequência pelos estudiosos do tema se refere ao cachimbo muito comum no oriente conhecido como "narguilé", de origem persa. ${ }^{24}$ Diversos especialistas teceram essa relação, considerando a "maricas" uma "imitação grosseira" desse artefato oriental. O narguilé, que podia ser "de latão, porcelana, marfim, bambu", vidro e outros materiais, era reconhecido como "[...] um frasco com água através do qual passam os vapores que se evolam da planta queimada e que são aspirados pelos fumantes" e ostentavam "as formas mais curiosas". (PEREIRA, J., 1958, p. 130)

Evidentemente, a "maricas" apresenta semelhanças inegáveis com o narguilé no seu funcionamento. A lógica comum é o resfriamento da fumaça no líquido, em geral água, antes de ser tragado pelo fumante. Havia ainda outro elemento característico desse cachimbo apreciado por aqui: o barulho produzido pelas bolhas na água, um "ruído especial" que também agradava aos "bondos" encontrados pelos oficiais portugueses.

Rodrigues Dória (1958, p. 5) já havia destacado esse dado ao notar que "canoeiros e barcaceiros" apreciavam "[...] o borborinho que, ao atravessar, a água produz a fumaça sorvida em profundos tragos". E Garcia Moreno (1958, p. 157) aponta alguns significados atribuídos pelos usuários que confirmam essa perspectiva: "A maricas [...] teria duas vantagens, no de-

24 Em inglês é referido como "water-pipe" ou "hubble-bubble". As expressões remetem a essas duas características: a existência de um recipiente que é preenchido com água para esfriar a fumaça e ao barulho produzido pelas bolhas de fumaça ao atravessar o líquido. 
poimento dos viciados: lavaria a fumaça, evitando náuseas e vômitos, e produziria um gorgolejo de grande valor humoristico, por ocasião da embriaguez".

Duas vantagens para o historiador quer dizer dois significados: por um lado, minimizar a irritação causada pela temperatura elevada do vapor, ou seja, a técnica era um eficiente mecanismo de "redução de danos", pois, como percebeu José Lucena (1958, p. 233), os fumantes utilizavam "vários recursos empíricos" para "prevenir surpresas"; por outro, inseria um elemento considerado fundamental à prática, um estimulante para alcançar os efeitos desejados.

Sendo assim, percebendo que as técnicas de fumar possuíam sentidos diretamente ligados à prática, deduzimos que a maior ocorrência de uma ou de outra em diferentes espaços geográficos pode indicar que diferentes valores e comportamentos associados ao uso da maconha predominavam em contextos específicos desse consumo. Esse aspecto nos leva de volta à África para compreender que se trata de uma prática híbrida na qual convergem contribuições orientais e africanas.

Estudos históricos, antropológicos e etnobotânicos têm esclarecido a dinâmica da introdução, difusão e transformação dos usos da Cannabis no continente africano. Essas abordagens lançam mão de descobertas arqueológicas, a exemplo de cachimbos dos séculos XIII e XIV com resíduos da erva, documentos históricos clássicos e evidências etnolinguísticas. (BENET, 1975; VAN DER MERWE, 1975) Entre esses, a tese mais aceita é a da introdução da cultura da planta na África por intermédio de povos árabes, como demonstra o mapa a seguir. 
Figura 14 - Difusão da maconha na África a partir do século XII

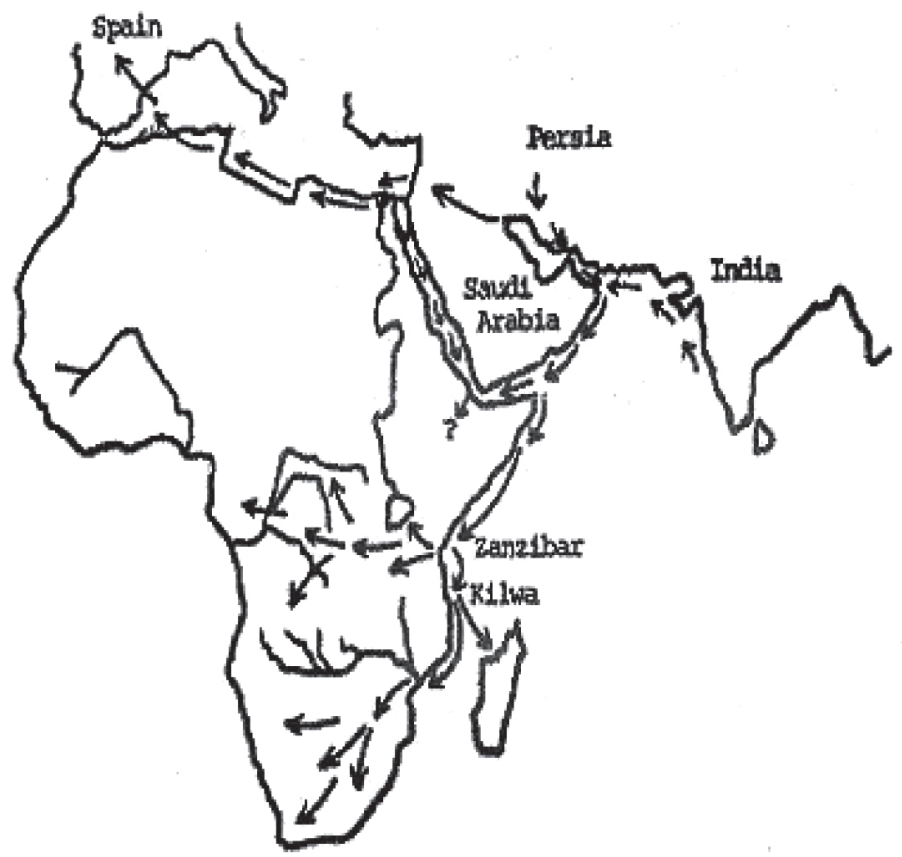

Fonte: Toit (1975, p. 85).

Em linhas gerais, a maconha teria sido trazida da Índia, primeiramente, para a costa leste da África por comerciantes árabes através de rotas comerciais que ligavam o sul da Arábia ao nordeste do continente. Essas rotas levavam ao interior e eram realizadas, sobretudo, seguindo o curso dos rios e através da navegação em suas águas. A partir do século XII grupos árabes teriam se estabelecido no continente, fixando assentamentos permanentes para facilitar o comércio com o interior. Nesse processo entraram em contato com povos "bantu" que residiam na costa leste africana e estes passaram a adotar o costume, assim como, a técnica do cachimbo com água empregada pelos árabes. A Cannabis, então, teria se expandido para 
a África central e daí para a costa oeste com as rotas comerciais de diversos povos ao longo da bacia do rio Congo, a exemplo de comerciantes swahili vindos da região dos Grandes Lagos. (TOIT, 1976, p. 25-28)

No mapa é possivel identificar três eixos de difusão no continente, tendo a costa da região nordeste como ponto de partida: um que desce e se bifurca em Kilwa para alcançar Madagascar e o extremo sul; outro que segue a costa até Zanzibar, onde toma o sentido oeste para difundi-la na porção central e na costa atlântica; e um terceiro na direção do norte, seguindo a costa mediterrânica da África onde alcança a Península Ibérica. Dessa forma, é possivel ter uma ideia do conjunto de elementos culturais diversos que estão contidos na prática. Ao longo desses caminhos, rituais, usos e técnicas foram transformados, interagindo com os fatores socioculturais regionais, a exemplo da adaptação das funcionalidades do narguilé oriental para as cabaças e chifres que deram nova forma ao cachimbo. Ademais, novos termos surgiram influenciados por variações linguísticas locais. É sobre esse último aspecto que trata o mapa a seguir.

O mapa mostra diversos nomes que a maconha recebeu na sua difusão pelo continente africano. As interações entre diferentes culturas transformaram os vocábulos-matrizes banghou bangi, usados na Índia, e haschisch, empregado pelos árabes, à medida que o costume era mais amplamente adotado, o que gerou novas palavras. Por exemplo, os thonga a chamavam de mbange, os shona da Rodésia diziam mbanji, e os swahili, da região dos Grandes Lagos, usavam bhangi, transformações dos termos de origem hindu citados acima.

Os hotentotes empregaram o termo daXab, muito próximo, fonética e etimologicamente, do termo árabe. Houve ainda variações bastante distantes das expressões originais como 
Figura 15 - Nomes da maconha na África no seu processo de expansão pelo continente

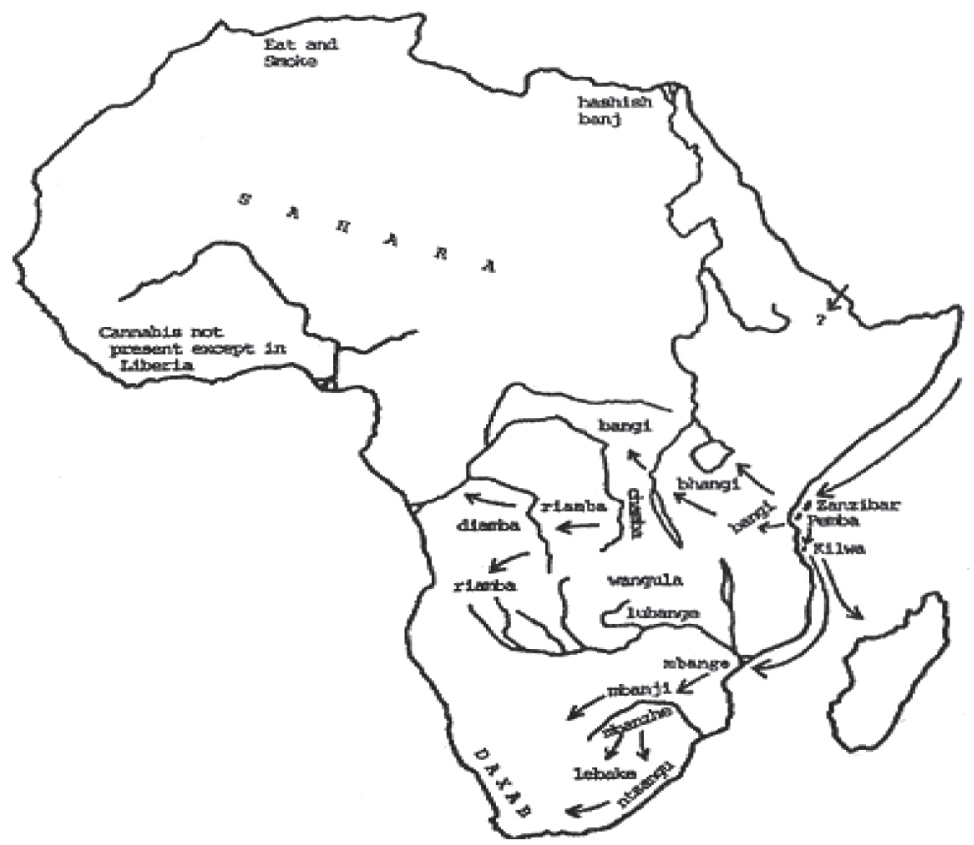

Fonte: Toit (1976, p. 35).

lebake, usada pelos sotho, e wangula, falada pelos lamba. Os povos de língua kimbundo, por sua vez, foram os criadores dos termos riamba, diamba e liamba, nomes também usados no Brasil para se referir à Cannabis. (TOIT, 1976, p. 35) Além desses, há outros termos da língua kimbundo bastante similares à palavra "maconha", como kangonha, que se referia à própria erva, e makanha, que podia expressar diversas coisas relativas a fumo e ao ato de fumar. ${ }^{25}$ (ASSIS JÚNIOR, 1947)

25 Uma curiosidade são os termos kimonha e umonha, que significam "preguiça", e são também foneticamente bastante próximos da palavra "maconha”. Respectivamente nas páginas 131 e 370 do dicionário citado. 
Seguindo a trilha das evidências linguísticas é possivel evidenciar o heterogêneo processo de difusão e apropriação cultural da Cannabis no mundo. Atravessando continentes através de rotas comerciais, a planta teve seu consumo incorporado ao repertório de práticas de diversos povos, de diferentes maneiras. Nesse bojo, as formas e técnicas que lhe acompanhavam iam sendo transformadas, de acordo com os contextos locais, gerando novos significados e simbolismos que, por seu turno, foram transmitidos e reconstruídos em lugares cada vez mais distantes. (TOIT, 1976)

O aspecto linguístico não passou despercebido pelos especialistas do proibicionismo ao longo da primeira metade do século XX, tendo sido frequentemente utilizado por eles para confirmar a tese da origem africana da maconha no Brasil. Os termos empregados para se referir à maconha, levantados em seus estudos, nos quais buscavam corroborar essa tese eram: "diamba", "riamba", "liamba" e "fumo de Angola". Contudo muitos outros, africanos ou não, foram citados: "dirijo", "tauari", "pango", "maruamba", "marigonga", "chá”, "atchi”, "birra”, "fumo brabo", "fumo de caboclo" e até "macumba". (FREYRE, 2003b, p. 479; ROSADO, 1958, p. 85)

Não estavam equivocados ao identificar sinonímias nas expressões empregadas para se referir à erva aqui e na África, contudo o fizeram numa chave racista, buscando mais uma confirmação da vingança do colonizado contra o colonizador. ${ }^{26}$ É infrutífero tentar estabelecer essa origem, visto que tanto portugueses quanto africanos já a conheciam antes de apor-

26 É o que Júlio César Adiala chama de "valoração racial da maconha". O artigo do fundador dessa perspectiva, o dr. Rodrigues Dória, relaciona as características atribuídas por ele à "raça negra" às da planta. Sendo assim, do lado da "raça" tem-se ignorância, resistência, intemperança, fetichismo e agressividade, enquanto que da maconha tem-se degeneração, analgesia, vício, loucura e crime. Abre-se caminho então, para a naturalização do "problema da maconha". (ADIALA, 1986) 
tarem no Novo Mundo. (CARNEIRO, 2002a; ESCOHOTADO, 1989, 2004) Porém, não é inútil nem incorreto afirmar que, no Brasil, o hábito atravessado de inúmeras influências culturais tem na África sua fonte mais forte de referências.

Sabe-se muito pouco, no entanto, sobre a presença da maconha e os seus usos entre africanos por aqui antes do século XX, são de conhecimento geral um relato e outro de viajantes letrados e algumas hipóteses de estudos etnológicos e antropológicos. ${ }^{27}$ (MOTT, 1986) As evidências mais diretas datam do século XIX já no período imperial, praticamente inexistindo para a colônia. Para esse último período existe uma conjectura feita por Edison Carneiro (1966, p. 18) acerca do seu uso no quilombo de Palmares:

Nos momentos de tristeza, de banzo, de saudade da África, os negros tinham à mão ali a liamba, de cuja inflorescência retiravam a maconha que pitavam por um canudo de taquari atravessando uma cabaça de água onde o fumo se esfriava”. O estudioso menciona o uso no século XVII do mesmo mecanismo descrito por Capelo e Ivens na sua expedição pela África no século XIX, apresentada anteriormente, que também é o mesmo empregado no Brasil do século XX, como já vimos.

Ao que parece, Edison Carneiro retirou essa informação de fontes holandesas, pois a complementa afirmando que, segundo esses estrangeiros, os cachimbos "eram feitos com os cocos das palmeiras". Contudo, não nos fornece mais pistas capazes de aprofundar e atestar essa possibilidade. Não seria de todo improvável, pois como se tem acompanhado, a Cannabis possui

27 A falta de referências ao hábito na pesquisa que realizou sobre os escravos em anúncios de jornais do século XIX causou o estranhamento de Gilberto Freyre: "Não encontro referências diretas à maconha ou diamba, sendo provável, como já insinuei, que entre os cachimbeiros e bebedores de fumo, houvesse os viciados no uso puro, ou misturado, do entorpecente africano". (FREYRE, 1979 apud MOTT, 1986, p. 125) 
uma longa trajetória e extensa presença no continente africano, contribuindo decisivamente para as práticas e o complexo cultural ligados aos seus usos no Brasil. Dessa forma, apesar da carência de provas, é muito factivel que os africanos que habitavam Palmares a cultivassem e consumissem, assim como faziam do outro lado do Atlântico. E não apenas nos "momentos de tristeza" e "saudade da África" como sugere o estudioso.

Uma referência feita pelo jesuita Fernão Cardim em fins do século XVI a um certo fumo pode ser analisada para definirmos se ele tratava da erva:

A alguns faz muito mal e os atordoa e embebeda; a outros
faz bem e lhes faz deitar muitas reimas pela boca. As mu-
lheres também o bebem, mas são as velhas e enfermas,
porque ele é muito medicinal, principalmente para os do-
entes de asma, cabeça ou estômago, e daqui vem grande
parte dos portugueses beberem este fumo, e o tem por
vício ou preguiça, e imitando os indios, gastam nisso dias
e noites. (CARDIM, 1939, p. 152)

Malgrado o padre não ter citado o nome da erva, é possível tirar algumas conclusões. Era impossivel a Cardim nomear aquele fumo, caso fosse maconha, com seu nome científico, pois isso só seria feito pelo botânico sueco Carl Lineu em 1753. Não se sabe se o religioso português tivesse conhecido a África em algum momento da sua vida antes de vir ao Brasil, o que poderia lhe ajudar a reconhecer semelhanças no fumo que descreve. Porém, sabe-se que a Cannabis não era desconhecida dos europeus, que a utilizavam, principalmente, para fazer papel, tecidos e combustivel de iluminação pública. Se for verídica a ideia de que o seu consumo psicoativo não era muito difundido na Europa, existe ainda o fato de viver em Portugal um grande número de africanos nos inícios da era colonial, o que poderia colocar o frei em contato com o hábito, já existente nesse continente. (SCHWARTZ, 1988) 
Os efeitos da erva se mostravam diferentes em quem fumava, atordoando e embebedando alguns, mas fazendo bem a outros. Cardim observa que não só os homens a consumiam e anota uma predominância do uso medicinal entre as mulheres. A erva poderia ser empregada como medicamento em problemas de "asma, cabeça e estômago", assim como assinalaram séculos depois o guia médico de Chernoviz, a propaganda das Cigarrilhas Grimault e o auto de exame toxicológico do Inquérito policial de 1940, abordado páginas atrás. Tais dados favorecem a hipótese de que se trata da maconha.

Esses usos, por sinal, não se restringiam ao medicinal, podendo ser também lúdico e recreativo, por "dias e noites", o que o jesuíta considerou "vício ou preguiça". Outro dado importante é que diferentes grupos sociais usavam-na, nesse caso, Cardim destaca índios e portugueses. "Grande parte" desses "bebia o fumo", ${ }^{28}$ um hábito que teriam adquirido dos índios. Isso pode revelar, caso o fumo em questão seja a maconha, que o seu consumo havia sido incorporado às culturas locais. Porém, as culturas amerindias possuíam um arsenal extremamente diversificado de substâncias psicoativas produzidas a partir de plantas e faziam largo uso do tabaco. Sendo assim, é possivel que o frei estivesse tratando de qualquer uma delas.

Alusões mais evidentes se encontram no século XIX. Tomem-se rapidamente duas: uma na primeira e outra na segunda metade do século. Em 1830, em sessão do dia 4 de outubro, a Câmara Municipal do Rio de Janeiro editou uma série de posturas, dentre as quais a que consta no parágrafo $7^{\circ}$ : "É proibida a venda e o uso do 'Pito do Pango', bem como a conservação dele em casas públicas: os contraventores serão multados,

28 A expressão "beber fumo" não indicava necessariamente um consumo da erva na forma de chá, mas era como se designava a prática de fumar naquele contexto. 
a saber, o vendedor em 20\$000, e os escravos, e mais pessoas que dele usarem, em 3 dias de cadeia”. (DÓRIA, 1958, p. 14) Provavelmente, trata-se da primeira proibição oficial de substância psicoativa no Brasil.

"Pito do Pango" foi uma das expressões utilizadas para nomear a maconha aqui, conhecida e bastante mencionada pela literatura proibicionista. Sobre ela, diz Parreiras (1958, p. 245), membro da CNFE: "O Pito de Pango é expressão africana que lembra algo que provém de Pungo, um dos distritos do Congo". Manuel Querino (1927 apud FREYRE, 2003a, p. 479), por outro lado, menciona que "pungo" era um dos termos que designavam a maconha na Bahia em fins do século XIX. O primeiro buscou estabelecer a conexão com a África com o objetivo racista que já foi discutido, encontrando no Congo a origem da expressão "Pito de Pango". O segundo nos dá um indício de variações linguísticas ocorridas no Brasil, afirmando que a maconha já foi reconhecida na Bahia pelo nome dessa região africana.

A primeira metade do século XIX no Brasil foi um período de grande ebulição: transferência da corte portuguesa, mudança de regime político, intensificação do tráfico transatlântico de escravos, crescimento demográfico e revoltas de todos os tipos, com destaque para as escravas. A postura municipal da corte em 1830 parece fazer parte de um projeto maior com o objetivo de disciplinar o espaço público, tanto as relações de trabalho quanto os momentos de lazer. O "Pito de Pango" poderia estar diluindo por demais essas fronteiras, exigindo a ação da municipalidade. Note-se a expressa menção aos escravos, grupo extremamente numeroso na corte e no país naquele contexto, com o crescimento do tráfico, e que já vinha se chocando com as iniciativas controladoras dos poderes públicos. (GOMES; 
SOARES; FARIAS, 2004; MARQUESE, 2006; MAXWELL, 2000; REIS, 2003)

A medida proibia a "venda" e a "conservação" da maconha em "casas públicas" da cidade, o que parece evidenciar a existência de estabelecimentos que comercializavam a erva, tentando a Câmara coibir esse comércio. Se havia quem vendesse é por que havia uma produção e seus compradores: os agentes desse comércio poderiam ser "escravos e mais pessoas", ou seja, livres e libertos. As penalidades são severas: cadeia para o comprador e multa para o vendedor. $O$ valor da multa, por sinal, é uma soma altíssima, nada mais nada menos que 20 mil réis. Em meados do século XIX era possivel comprar cerca de uma arroba de carne com 5 mil réis. (REIS, 1993, p. 8) Diante do rigor da medida, pode-se conjecturar que o comércio do "Pito de Pango" na corte fosse significativo a ponto de chamar a atenção dos legisladores da cidade.

$\mathrm{Na}$ segunda metade do XIX existe mais um relato: o do cônsul inglês Richard Burton. Tendo ido à mina de Morro Velho em 1868, descreveu da seguinte forma o que viu: "Os negros de Minas Gerais se deliciam também com o pango, aqui chamado 'ariri', a bem conhecida Bhang (Cannabis sativa) da Índia e da costa leste e oeste da África. São capazes de pagar prontamente até 1 \$000 por um punhado desse veneno". (BURTON, 1941 apud MOTT, 1986, p. 126) O cônsul e orientalista é uma das raras testemunhas oculares que se conhece a mencionar a prática antes do século XX.

Burton se refere à maconha, primeiro, como "pango", o mesmo termo visto agora a pouco empregado na Postura $\mathrm{Mu}-$ nicipal da corte em 1830. A seguir, nos informa que naquela região do interior de Minas Gerais era chamada de "ariri". Pra dirimir qualquer dúvida afirma ser a erva a "conhecida Bhang", a identificando ainda pelo nome científico, Cannabis sativa. 
Como vimos, "Bhang" é o vocábulo indiano que serviu de matriz para outros surgidos na difusão da planta pelo continente africano. Portanto, para o inglês, não havia dúvidas de que se tratava da maconha.

Nas suas palavras sugere que os negros da região muito apreciavam a erva, "se deliciavam" com ela. Burton pode estar considerando como negro apenas os africanos, escravos ou libertos, ou pode estar incluindo também os seus descendentes nascidos no Brasil, comumente chamados à época de crioulos. No entanto, só menciona os negros como usuários, silenciando sobre portugueses, indígenas e mestiços. Evidencia também haver algum tipo de circuito comercial: se pagava até mil réis por "um punhado", valor considerável que poderia equivaler a três quilos ou mais de carne. Outro dado importante é o fato de Burton ter apontado o trajeto de expansão dos usos da maconha, da Índia à costa atlântica da África, antecipando em um século os primeiros estudos que traçariam esse percurso. Por fim, revela uma perspectiva tendente à reprovação daquele hábito, pois considera a erva um "veneno", parecendo até se surpreender com a disposição dos indivíduos em pagar aquela quantia por um punhado.

No que pese a ausência quase absoluta de fontes e a falta de comprovação mais efetiva de algumas referências, essas evidências nos levam a crer que o consumo de maconha constitui uma prática antiga no Brasil. Ocorria no litoral e no interior, movimentando relações comerciais nada despreziveis para o custo de vida cotidiano da maioria da população. Além disso, pode ter se tornado tão visivel e disseminado que causou a desaprovação do poder público. O próprio silêncio dos relatos históricos se, por um lado, depõe a favor das dúvidas acerca da importância da prática nas sociedades colonial e imperial, formando uma lacuna dificil de preencher, por outro, pode indicar 
algo da percepção daquelas sociedades em relação ao hábito. Talvez fosse considerado tão comum e não problemático que não despertou maiores interesses dos olhares contemporâneos. Suposições, enfim.

De volta ao século XX, na literatura do proibicionismo e em outros estudos, foram apontadas duas diferentes reuniões coletivas em que haveria consumo de maconha: os cultos das religiões afro-brasileiras e o chamado "clube de diambistas". Receberam diversos nomes indistintamente, principalmente, o de "assembleia". Havia uma distinção entre elas, tomando como base o papel assumido pela erva na ocasião. No primeiro caso, a maconha não seria o motivador da reunião, mas seria incorporada como um dos vários elementos de culto, enquanto que no segundo, a reunião acontecia para o consumo da erva, por isso foi tomada como a imagem mais representativa do seu "caráter gregário".

Sobre a relação da maconha com as religiões afro-brasileiras há um enorme silêncio das fontes primárias. Apesar da grande publicidade dada aos usos da erva na década de 1950 pelos jornais de Salvador e até mesmo do interior do estado, não foi encontrado sequer um caso nas matérias. E mesmo na década de 1940 nada foi encontrado. Isso contrariou bastante as expectativas da pesquisa que, partindo de textos e estudos que assinalavam com certa frequência essa relação, esperava encontrar a presença da erva nos conflitos entre autoridades e o "povo de santo", ainda comuns na época. Restaram, então, algumas sucintas alusões muito pouco descritivas feitas pelos especialistas do proibicionismo e outros estudiosos na primeira metade do século XX.

Entre esses estudiosos podem ser citados Gilberto Freyre, Manuel Querino, Câmara Cascudo e Arthur Ramos. Freyre mencionou a presença da maconha entre os negros no Brasil, 
antes e depois da escravidão, em diversas obras, a exemplo de Nordeste, Sobrados e Mocambos e, o clássico, Casa Grande \& Senzala. Em linhas gerais, nos seus escritos a erva tomou um caráter dual: seria, juntamente com as religiões, um dos traços da cultura negra que mais estaria resistindo à "desafricanização"; mas, também teria sido um recurso aos escravos que não conseguiam "achar gosto na vida normal", abusando dela e da aguardente, piorando-lhes o "banzo" e deixando-os "lesos", "penando". (FREYRE, 2003a, p. 553) Quanto à sua presença em cultos religiosos afro-brasileiros, diz (FREYRE, 1979 apud MOTT, 1986, p. 125-126): “Os negros trouxeram a maconha para o Brasil e aqui cultivaram como planta meio mística, para ser fumada nos candomblés e xangôs, pelos babalorixás e pelos seus filhos". Teria ela essa característica "meio mística", pois suas folhas e inflorescências quando fumadas "fechavam o corpo do crente e lhe davam sonhos de amor". (FREYRE, 1968 apud SOUZA, 2004b, p. 94)

Câmara Cascudo (1937, p. 35) observou que a erva era inclusive conhecida como "macumba" em regiões do Nordeste, assim como o fez Manuel Querino (1927 apud FREYRE, 2003a, p. 479) especificando a ocorrência da expressão na Bahia. "Macumba" é um termo bundo empregado para se referir às religiões afro-brasileiras em diversas partes do país, designando também um instrumento percussivo tocado nos cultos, porém, atualmente traduz uma forma pejorativa de tratar essas religiões. Querino, diga-se de passagem, é citado como fonte de informação por Freyre e Arthur Ramos. Este último, observando um rito de iniciação de candomblé em Salvador no início do século XX, não consegue identificar as folhas utilizadas, mas toma relato de Querino sobre a cerimônia como base para concluir que entre elas estava a maconha. (RAMOS, 1951) 
Esses pioneiros dos estudos sobre a cultura no Brasil no século XX foram unânimes em afirmar que o consumo da maconha era uma prática predominantemente marcada pelo universo cultural do negro. Contudo, nem todos foram testemunhas oculares do seu uso religioso, a maioria teve conhecimento através de relatos, sendo Manuel Querino, talvez, o único a presenciar e identificá-la, já que Arthur Ramos supôs, partindo de uma afirmação sua.

Não há como não lamentar a falta de uma análise mais detida, que buscasse comprovar estar mesmo a Cannabis presente entre as plantas rituais, que procurasse identificar quais os usos feitos de quais partes da planta e em quais rituais especificamente, bem como tentasse compreender os significados adquiridos por ela em cada contexto e os sentidos atribuídos pelos participantes. Ainda assim, alguns elementos podem ser extraídos.

Em Freyre se pode identificar diversas características que seriam próprias da maconha como elemento religioso: planta de poder e afrodisíaca, presente em diversas regiões e na várias expressões da religiosidade afro-brasileira, usada tanto pelos sacerdotes quanto pelos filhos de santo. Este autor parece até sugerir que esse aspecto do uso da maconha denotasse alguma diferença entre os usos no Brasil e na África, pois afirma que os negros a trouxeram e "aqui cultivaram como planta meio mística”, entretanto, não confirma.

Cascudo, Querino e Ramos trazem ainda mais elementos. Ao anotarem como a erva e a religião podem ter sido designados pela mesma palavra, pode-se supor que a mesma já possuiu importância tal dentro dos cultos capaz de fazer confundir uma à outra, ou ainda, que a sociedade a percebesse intrinsecamente ligada à religião dada a sua visivel presença nos terreiros e nas cerimônias. Os dois últimos presenciaram o 
uso religioso da Cannabis em rituais de iniciação de candomblés baianos, o que já pode dizer algo sobre os usos que dela se fizesse naquelas ocasiões: é possivel que fosse empregada para produzir o êxtase no iniciado, no Pai de Santo ou Mãe de Santo, ou nos demais presentes; é possivel também que fosse identificada com algum orixá, provavelmente o do iniciado e lhe servisse como oferenda; ou ainda como planta de poder no intuito de dar proteção ao iniciado ou aos demais. São essas algumas especulações possiveis de serem feitas.

Não foram apenas essas as referências feitas a uma possivel relação entre religião e maconha. Os médicos e demais especialistas do proibicionismo das décadas de 1930 e 1940 também mencionaram. Esse aspecto já estava presente desde o início em Rodrigues Dória, fundador do discurso condenatório da maconha. Diz ele:

Nos 'candomblés' - festas religiosas dos africanos, ou dos pretos crioulos, deles descendentes, e que lhes herdaram os costumes e a fé, é empregada para produzir alucinações e excitar os movimentos nas danças selvagens dessas reuniões barulhentas. (DÓRIA, 1958, p. 6)

Além dos terreiros da Bahia, também seria fumada nos "catimbós" de Pernambuco e nos "sambas e batuques", os "xangôs" de Alagoas. Curiosamente, nada diz sobre esse uso nas casas de culto afro-brasileiro de sua terra natal, Sergipe.

Rodrigues Dória mal consegue disfarçar seu preconceito e caracteriza as festas de santo como "reuniões barulhentas" permeadas de "danças selvagens". A erva, com larga presença geográfica na região Nordeste, teria a função de "produzir alucinações e excitar os movimentos". Como foi visto, o médico estava imbuído de uma visão etnocêntrica de cultura e tinha o seu referencial teórico informado pelas teses do racismo científico que penetravam os espaços politicos e intelectuais do país 
desde pelo menos a década de 1870. Formado pela Faculdade de Medicina da Bahia, aonde logo viria a lecionar, político e membro de uma grande família aristocrática sergipana, Dória tendia a reproduzir aquele programa teórico. No que diz respeito ao uso religioso da maconha, limitou-se a afirmar que a erva era utilizada pelas suas propriedades alucinatórias e euforizantes, dispensando qualquer comentário sobre os significados que viesse a ter naquelas cerimônias.

Mais dois médicos adicionaram alguma informação sobre isso, foram eles Garcia Moreno e José Lucena. O primeiro, diretor do Serviço de Assistência a Psicopatas de Sergipe, comenta a repulsa dos pais e mães de santo do Recife na década de 1940 às ideias de que a maconha era "vício de negro" e fazia parte das suas cerimônias religiosas. Comentando, afirma que aqueles líderes religiosos alegavam ser a expressão "fumo de caboclo" um atestado da origem ameríndia do hábito. Segundo o doutor, essa recusa e relação com o indígena eram uma "projeção defensiva", uma "boa escapadela e uma excelente defesa" que os "descendentes do negro" encontraram para os "seus ancestrais". Por seu turno, José Lucena, assistente do Serviço de Higiene Mental de Pernambuco, chega a dizer que esse setor recebeu denúncia de um terreiro do Recife "contra um catimbó em que se consumiria liamba", pois este estaria "zeloso da ortodoxia". (LUCENA, 1958, p. 210)

As referências dos doutores são sumárias, mas tratam diferentes aspectos do mesmo assunto, tendo como cenário a capital pernambucana. A recusa e a denúncia dos terreiros, caso tivessem ocorrido realmente, podem ter diferentes sentidos. Poderiam estar certos os dois médicos e os terreiros do Recife estariam usando um argumento etnolinguístico para se defender das acusações em relação ao uso religioso da maconha. Além disso, apropriavam-se do mecanismo de repressão 
oficial para combater a prática internamente. Por outro ângulo, à luz do contexto histórico, décadas de 1930 e 1940, é possivel compreender o lugar de tal postura defensiva, podendo fazer parte de uma estratégia mais ampla de lutas sociais por legitimação das religiões afro-brasileiras. A denúncia poderia indicar os conflitos internos deste processo, que com certeza não foi homogêneo nem vivido igualmente pelas diferentes realidades regionais e seus terreiros.

Ou poderiam mesmo estar narrando o exato processo histórico da difusão dos usos da maconha no Brasil, tendo o indígena como protagonista. Lembre-se que uma forte característica da religiosidade afro-brasileira é a presença do "caboclo" como símbolo do elemento nativo ou da sua interação com os demais grupos culturais. Isso é particularmente intenso em Pernambuco, onde existem terreiros dedicados quase que exclusivamente ao culto do "caboclo". Assim como os fatos relatados podem ser apenas mais referências sem comprovação ou invenção do discurso proibicionista dos médicos.

Como dito, na década de 1950 as matérias de jornais soteropolitanas silenciaram sobre esse fenômeno. Não existia ou não foi encontrado pelas autoridades nas "batidas" que faziam nos terreiros? Desapareceu ou passou a ser cada vez mais encoberto nos terreiros? Não é impossivel que a intensa repressão e a rápida condenação moral do hábito possam ter levado a seu ocultamento cada vez maior no interior dos terreiros e mesmo ao seu abandono, tanto como parte da estratégia de legitimação social da religião a partir de meados do século XX quanto devido à absorção dessa perspectiva pelos seus adeptos. (MACRAE; SIMÕES, 2000)

Um aprofundamento nesse aspecto necessita de estudos específicos, podendo contribuir bastante para o conhecimento sobre os significados atribuídos pelos usuários ao seu uso nos 
diversos contextos e tipos de relação que tiveram com a planta. Porém esse estudo mais detido e demorado passa ao largo das possibilidades desse trabalho.

A alteração dos estados de consciência é uma prática encontrada de forma recorrente na dimensão religiosa das sociedades humanas em todo o mundo, podendo ser estimulada por técnicas de meditação e respiração, pela música, pelo consumo de psicoativos, chamados também de enteógenos. O uso religioso de substâncias psicoativas feitas com plantas, sendo fumadas ou bebidas, era bastante difundido na América. Exemplos dessas plantas são o peyote e a datura no norte do continente, a folha de coca na região dos Andes, bem como o tabaco e o cauim no Brasil. ${ }^{29}$ Poderiam ser de uso generalizado ou restrito aos xamãs como planta de poder. Algumas, inclusive, faziam parte das oferendas dos deuses e outras eram tratadas como espíritos. (CARNEIRO, 2005; CASTAÑEDA, 1968; ELIADE, 1998; ESCOHOTADO, 1989, 2004; LABATE, 2008)

A Cannabis possuiu variados usos religiosos no mundo através dos tempos. Existem evidências desde a antiguidade, aparecendo até em textos sagrados de diversas religiões. Sobre essa forma de uso na América ainda faltam maiores referências e trabalhos específicos capazes de esclarecer as diversas faces que tenha tido na história. Para a sua presença nas religiões afro-brasileiras, apesar de comentários e possiveis observa-

29 Assim como o tabaco a bebida denominada cauim poderia também ser consumida em situações não religiosas e tinha singular importância para diversos grupos indígenas no Brasil colonial. Hans Staden, o marujo alemão que ficou famoso por ter publicado suas viagens à América no século XVI, menciona que um dos ingredientes da beberagem (o milho, a mandioca ou talvez o caju) costumava causar conflitos entre colonos e tupinambás na costa paulista atual, pois havia uma grande quantidade em terras ocupadas pelos europeus sobre as quais avançavam os indigenas para colhê-las quando estavam maduras. O marujo ainda assinala que a bebida era consumida pelos tupinambás "quando comiam os inimigos", evidenciando outro possível emprego da substância. (STADEN, 1900, p. 41) 
ções, quase nada se sabe. De qualquer forma, fica evidente a diversidade de percepções sociais desse fenômeno num contexto de proibição e repressão no século XX.

Partimos então para a outra reunião coletiva apontada pelos especialistas na questão do "caráter gregário" do consumo de maconha. A cena descrita por Alberto Deodato no seu livro Canaviais páginas atrás foi repetidamente citada nos textos dos especialistas produzidos nas décadas seguintes, sendo posta ao lado de outras presenciadas pelos doutores. Como vimos há pouco, a ocasião narrada pelo escritor era bastante semelhante àquela narrada pelos oficiais portugueses em expedição pela África central nos fins do século XIX.

Na literatura do proibicionismo da maconha, a situação de uso coletivo recebeu diversos nomes, principalmente o de "assembleia", e a imagem mais representativa deste aspecto era o chamado "clube de diambistas". Não há fontes que confirmem se essa última expressão era usada pelos próprios usuários para designar suas reuniões. Ao que tudo indica, foi atribuída pela literatura do proibicionismo a essa prática amplamente difundida em certas regiões do Nordeste, para os especialistas, notadamente, nos estados "de maior influência africana". (PERES, 1958, p. 68)

Em verdade, o próprio dr. Rodrigues Dória, pioneiro do discurso médico condenatório da maconha, já tinha se referido a esse fenômeno nas feiras de Sergipe sem, contudo, empregar a expressão e antes dele, Alfredo Brandão, médico formado pela Faculdade de Medicina da Bahia, em seu livro Viçosa de Alagoas. Entretanto, foi Francisco de Assis Iglésias o primeiro a usar a expressão "clube de diambistas" em seu artigo intitulado "Sobre o vício da diamba" nos fins da década de 1910. É dele a conhecida descrição da sessão de um "clube de diambistas", que assistiu no Vale do Mearim no Maranhão: 
Os fumantes reúnem-se, de preferência, na casa do mais velho, ou do que, por qualquer circunstância, exerce influência sobre eles, formando uma espécie de clube, onde, geralmente, aos sábados, celebram as suas sessões. [...] os fumadores estão, uns em volta de uma mesa, outros deitados em suas redes. Às primeiras baforadas os olhos se injetam de sangue: os primeiros sintomas de perturbação mental se manifestam. Alguns ditos chistosos, umas gargalhadas, indicam que o pessoal começa a embriagar-se, e versos toscos, com termos africanos, saem por entre baforadas de diamba:

Ô diamba, sarambanba!

Quando eu fumo a diamba,

Fico com a cabeça tonta,

E com as minhas pernas zamba

Fica zamba, mano? (pergunta um)

Dizô! Dizô (respondem todos em coro).

(IGLÉSIAS, 1958, p. 18-19)

Para concluir sua observação, o dr. Iglésias anota:

Dizô deve ser um termo africano que traduz a idéia de aprovação - sim. [...] O nosso matuto emprega o termo sem lhe conhecer a significação. Perguntamos a um assistente dessa sessão, o que queria dizer 'dizô', e ele nos respondeu textualmente: 'dizô', é sutaque de gente doida. (IGLÉSIAS, 1958, p. 19)

O "clube de diambistas" descrito acima se mostra uma reunião ritualizada com regras e um repertório de práticas. Assis Iglésias era agrônomo e observou o costume na viagem que fez ao interior do estado do Maranhão, quando integrou uma expedição médico-científica aos sertões nordestinos, chefiada pelos médicos Belisário Penna e Artur Neiva em 1912. (SILVA, 2009) O grupo se encontrava "geralmente aos sábados" na casa do mais experiente para celebrar. Essa informação não é aprofundada pelo autor, mas pode indicar que pessoas de diferentes locali- 
dades participassem do rito, pois, como se sabe, sábado é o dia da semana onde geralmente ocorrem grandes feiras temporárias na região Nordeste, em geral nas cidades que são importantes centros de comércio local. (FERRETTI, 2000) Na ocasião, fumam e caem em "gargalhadas" e "ditos chistosos", alternando "baforadas de diamba" e "versos toscos com termos africanos", o que para o cientista, imbuído da opinião médica contrária ao uso da maconha, era prova de "perturbação mental".

A partir de então a referência aos "clubes de diambistas" será constante e trará em comum os elementos apresentados acima: uma reunião na casa de alguém com status elevado no grupo, onde fumam, geralmente por meio do cachimbo, e proferem versos, em tom de desafio ou não, relativos à maconha, uma peculiaridade do uso no Brasil. Outros autores apresentam outras observações sobre essas reuniões, no que adicionam novos dados, aprofundando ora um ponto ora outro em relação a como funcionavam.

As conclusões dos especialistas sempre giravam em torno do grau de nocividade do uso. Isso seria comprovado pelos "efeitos discretos" que eram observados nos fumantes presentes às reuniões, o que seria o indício de um "maconhismo crônico". Aqueles já seriam "fumantes inveterados", analgesiados permanentemente e transformados em "idiotas". Como apresentavam um comportamento distante do modelo de usuário de maconha, vítima da "loucura canábica", ataque de fúria ocasionado pelo efeito da erva, o autor insere esse comportamento "discreto" em outra classificação, o "maconhismo crônico". Esses usuários, que tinham suas vidas normais, deveriam ser pequenos comerciantes que trabalhavam na feira de sábado ou trabalhadores rurais e pelo visto não estavam a causar problemas de segurança pública, pois o uso coletivo ritualizado regulava o consumo. 
Figura 16 - "Clube de diambistas" em Propriá, Sergipe

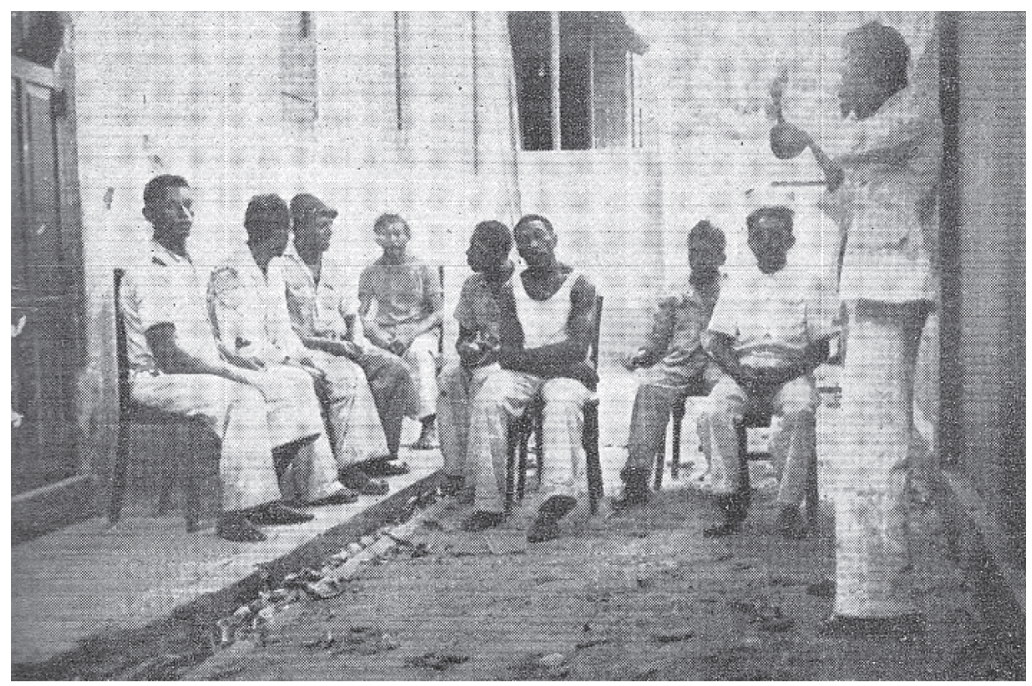

Fonte: Iglésias (1958).

O botânico Jayme Regalo Pereira (1958, p. 129) foi um dos que manifestou a preocupação com a "tendência para o uso da maconha em sociedade" no Brasil. Para este especialista em "plantas alucinatórias" havia entre os que a fumavam "[...] a convicção de que a diamba precisa ser usada em sociedade". A sua preocupação tinha como fundamento a ideia de que o grupo intensifica os efeitos euforísticos da droga no indivíduo, devido às brincadeiras e gargalhadas, e, assim, fornece indícios das práticas que compunham as reuniões:

As manifestações alucinatórias provocadas pela maconha variam conforme a indole e as tendências de cada indivíduo. Quando tomada ou fumada em conjunto, sujeito cada um às influências dos outros, sob chistes e galhofas dos demais, estimulados e espicaçados, integrados enfim no ambiente já por si só favorável à libertação dos instintos, tornam-se os intoxicados ainda mais eufóricos, mais inquietos, mais loquazes, mais expansivos, por vezes mais violentos. (PEREIRA, J., 1958, p. 129) 
Essas reuniões dos "clubes" eram espaços de sociabilidade, de uma sociabilidade onde não faltava a irreverência, a astúcia em demonstrar-se valoroso no grupo. Uma sociabilidade "picaresca" não muito bem vista pelos especialistas em maconha nesses tempos. ${ }^{30}$

O cientista habilmente monta um quadro alarmante com base nos elementos do discurso proibicionista. Em sua opinião, os usuários, para ele sinônimo de "intoxicados", ficariam gradualmente "mais eufóricos", "mais expansivos" e "mais violentos" como consequência da prática coletiva. Nota-se que Regalo pensa esse contexto social como um fator negativo, "por si só favorável à libertação dos instintos". Os efeitos tornam-se perigosos quando "tomada ou fumada em conjunto", já que individualmente seriam variáveis de acordo com a "indole e as tendências" de cada um. Contudo, esse modelo linear de relação com a droga não dava conta da multiplicidade de formas que ela assumia na realidade social, das quais o "clube de diambistas" era um exemplo.

É que no imaginário desses especialistas que fundamentaram a criminalização da maconha e de parte das elites intelectuais ressoavam duas referências de uso coletivo da erva. A famigerada seita dos haschischins comandada pelo Príncipe do Líbano, Hassam ibn Al-Sabbah, e imortalizada na história do "Velho da Montanha" narrada por Marco Polo, representava o arquétipo da "loucura furiosa" capaz do assassinato cruel. Por outro lado, o célebre "clube dos haschischins", formado por intelectuais franceses do século XIX como Baudelaire e Gautier, era o símbolo da depravação moral e da corrupção dos costumes.

30 Refiro-me aqui à ideia de "picaresco" que foi colocada por Batkhin na sua análise da cultura popular europeia durante a Idade Média e o Renascimento, evidenciando espaços de sociabilidade baseados no chiste, na ridicularização e na astúcia. (BAKHTIN, 1999) 
Os "clubes de diambistas" do Brasil não teriam, no entanto - na visão desses especialistas -, a sofisticação e o caráter elitizado de agrupamentos reunidos em torno de um monarca ou formados por intelectuais, seriam compostos pelas populações ribeirinhas da região Nordeste, pelo "matuto", pelo "sertanejo", enfim, pelo sujeito que esses especialistas consideravam como o mais oposto à modernidade e símbolo maior da parte "atrasada" do país. Nas palavras do agrônomo Leonardo Pereira (1958, p. 62-63) num relatório entregue ao Ministro da Agricultura, Indústria e Comércio em 1925, o engenheiro baiano Miguel Calmon Du Pin e Almeida, o "caboclo" que usava a maconha era "um imbecil e de uma indolência fantástica".

O "sertanejo", o "matuto", o "caboclo" esteve na mira das atenções da classe intelectual brasileira muito antes da apropriação nacionalista e cívica da política cultural da era Vargas. Durante a segunda metade do século XIX se identifica um crescente interesse das elites nacionais acerca da vida das populações no interior do Brasil, chamado genericamente de "sertão". Isso coincide com o crescimento das preocupações da medicina com a questão social e com os debates em torno da "identidade nacional". Desenvolviam-se, então, diversas leituras desses "sertões" cujo referencial comum era a "modernidade" e a posição que esse espaço ocuparia em relação a ela. (OLIVEIRA, 1998) Durante certo momento predominou uma leitura negativa do sertão e do sertanejo, que considerava esse povo atrasado e doente, organizando-se expedições médico-científicas para o interior, principalmente, nas regiões Norte e Nordeste. (SILVA, 2009) Paulatinamente, ao longo dos primeiros anos do século $\mathrm{XX}$, essa ótica passaria a conviver com outras.

Surgiam interpretações que tomavam o sertão como "essência" do Brasil, lugar que guardava a "nacionalidade", depositário das "verdadeiras tradições" e resistente à "marcha do 
tempo". Divergiam, no entanto, sobre a relação desse sertão com o "moderno". Para alguns, a modernidade era uma ameaça à "pureza" e "essência" nacionais do sertão, ela desconfiguraria a sua verdadeira face tradicional. Para outros, o sertão, ao mesmo tempo em que representava a identidade brasileira, estava às margens da história, necessitando ser "modernizado". Tais questões também revelam a dinâmica e os conflitos no interior das elites intelectuais nacionais, apesar do esforço comum de consolidarem a sua legitimação na sociedade. Esses debates tinham uma ligação direta com outra forma de pensar a "tradição". (FRANÇA, 2010; LIMA, 1999; NEVES, 2005; PÉCAUT, 1990)

Na busca de definir uma "autêntica cultura nacional", parte considerável dos intelectuais brasileiros no século XX passava a interpretar a ideia da "tradição" numa perspectiva valorizadora. Mais tarde essa nova leitura será aproximada de outra noção que experimentaria profunda revisão, sistematizada nos anos 1930 por Gilberto Freyre, a "mestiçagem". Se, por certo tempo, foi associada a "atavismo" e "atraso", ocupando o polo oposto da "ciência" e do "progresso", noções que tanto animaram as elites intelectuais no processo de transição política republicana, a "tradição" tornava-se o norte de "[...] uma 'essência' nacional, uma identidade última e profunda a ser descoberta na própria alma popular". (CUNHA, 2001; MELLO, 2009; SCHWARCZ, 1996)

Porém, longe de corresponder a um processo linear em que as novas ideias eliminam por completo as precedentes, essas leituras e interpretações do sertão, da miscigenação, da identidade nacional e da tradição conviveram juntas no espaço e no tempo, ainda que a perspectiva valorizadora tenha aumentado o número de adeptos e se tornado predominante entre os intelectuais. Os especialistas do proibicionismo da maconha no 
Brasil parecem ter admitido mais claramente, pelo menos em relação ao uso da droga, uma interpretação negativa do sertão e dos seus habitantes, pois encontravam no conjunto da vida desses os elementos favorecedores da difusão do hábito, considerado uma "toxicomania" perigosa.

O conhecido psiquiatra João Mendonça, em palestra durante a abertura de uma das reuniões da Sociedade de Medicina Legal, Criminologia e Psiquiatria da Bahia em 1944, faz uma medida da preocupação de sua classe com o uso da maconha no interior pelos sertanejos:

Para dar-vos, de início, uma idéia dos perigos sociais da maconha, digo-vos, tão só, à moda de intróito, que ela é, ao lado da cachaça, o enlevo das populações nortistas pobres $[\ldots]$ povo de caracteres étnicos que facilitam a absorção fácil de ideologias abstrusas, assoberbado pelos flagelos da seca, pelas torturas das endemias, e da ignorância, é de apavorar o quadro dantesco que, nesse terreno, os tóxicos podem desenhar [...]. (MENDONÇA, 1958, p. 99)

O usuário apresentado pelo psiquiatra era um degenerado em parte natural e em parte social. De um lado, seus "caracteres étnicos" o tornavam presa fácil de ideias confusas, por outro, o meio social o flagelava, o torturava, relegando-o à "ignorância". Nesse "quadro dantesco" a maconha era, juntamente com a cachaça, um verdadeiro "perigo social”. Na avaliação do cientista eram "pobres nortistas", vítimas passivas dos efeitos dos "tóxicos", que buscavam na maconha êxtase e alívio para a dureza inescapável da vida. Essa preocupação, com clamores de profilaxia, era transformada nas cobranças de ação enérgica que os médicos faziam às autoridades.

Parte dessa sociabilidade dos "clubes" se manifestava na prática de proferir versos sobre a maconha, por alguns especialistas chamados de "poesia da maconha", por outros de "trovas 
da maconha". ${ }^{31}$ Pelo que se sabe, um dos presentes pronunciava uma estrofe, em geral uma quadra, decorada ou improvisada, que poderia ser seguida de uma resposta em coro dos demais presentes ou receber uma resposta individual caso tomada como desafio por outro.

Poderia se referir à alguma questão do momento em que se dava o encontro, a fatos da comunidade e ainda abordar temas relativos aos usos da maconha. Quem respondesse demonstrava conhecimento dos códigos do grupo nos quais a prática se assentava, pois conseguia identificar e dar continuidade ao assunto tratado pelo antecessor; deveria resolver a charada e propor uma ao seguinte.

Essa parece ter sido uma peculiaridade do consumo coletivo de maconha no Brasil, pois não foi encontrada menção à prática nos estudos que abordam a questão em outras partes do mundo. Como se vê essa característica é fruto da convergência do uso psicoativo da erva com práticas presentes no vasto repertório cultural das classes subalternas. As trovas, poesias ou loas da maconha foram encontradas em diversas partes das regiões Norte e Nordeste, por vezes repetindo temas e versos, por vezes reelaborando-os com referentes e sentidos locais.

As trovas poderiam se referir à diversas questões. Observe-se uma recolhida por Garcia Moreno em Sergipe na década de 1940:

31 Anthony Henman na década de 1970, ao estudar o uso de maconha pelos índios tenetehara (ou guajajara) do Maranhão, mesma região de onde Iglésias recolheu os versos na década de 1910, identificou essa prática: "sobrevivem interpelações (em português) do tipo 'xinga a bicha', às quais deve-se responder com as 'loas' estabelecidas pela tradição”. (HENMAN, 1986, p. 104, grifo nosso) Rodrigues Dória já havia observado bem antes a sua presença em Alagoas atribuindo-lhe outra nomenclatura, no entanto, e comenta que a maconha era usada "[...] entre os que porfiam na colcheia, o que entre o povo rústico consiste em diálogo rimado e cantado em que cada réplica, quase sempre em quadras, começa pela deixa ou pelas últimas palavras do contendor". (DÓRIA, 1958, p. 5, grifo nosso) 
A Estrela D'Alva é bonita Quando vem rompendo a aurora

Passarinho canta e grita

Soldado na gurita

Cobre a cabeça com o véu

Planeta corre no céu $[\ldots] .^{32}$

(MORENO, 1958, p. 158)

São diversos os assuntos em questão aqui. A vigilância policial é abordada no verso "Soldado na gurita", onde a palavra "gurita" parece ser uma variação coloquial de "guarita", a "casinhola ou torre para abrigar sentinelas". (HOUAISS et al., 2004 , p. 380) Os cuidados a serem tomados por quem fuma é o assunto tratado no verso "Cobre a cabeça com o véu": é preciso se "encobrir" para não ser reconhecido, não se expor ou, como dizem usuários mais contemporâneos, não dar "bandeira", não "vacilar". (MACRAE; SIMÕES, 2003) Além disso, era preciso atenção e solidariedade entre todos para não ser pego de surpresa, como sugere "Passarinho canta e grita", indicando que algum usuário ficasse atento para avisar aos demais em caso de perigo.

Os tempos tinham mudado e parece que isso não era novidade para eles. Esses versos foram registrados na década de 1940, num momento em que o consumo de maconha já era considerado crime pelas leis nacionais. Sendo assim, era preciso alertar os outros, lembrá-los que deveriam ficar mais atentos se quisessem manter o hábito e os usuários sabiam que as "trovas" eram um eficiente meio de transmissão e ensinamento de experiências.

32 Nesse ponto cabe uma conexão provocativa: ao ouvir o pernambucano Bezerra da Silva cantar "Vou apertar, mas não vou acender agora/Se segura malandro, pra fazer a cabeça tem hora", não estariamos diante da atualização da estratégia, não tão distante dele, dos "diambistas" maranhenses?. (POPULAR; BOMBEIRO, 1986) 
Ainda Garcia Moreno, com versos de Propriá, Sergipe, demonstra que outras "trovas" poderiam afirmar individualidades e manifestar a opinião pessoal do trovador sobre o consumo de drogas:

\author{
Eu sou Enoque afamado \\ Porque não tem cirimonha \\ Em todo lugar que canto \\ Minha cara é sem vergonha \\ Deixei de beber cachaça \\ agora só tomo maconha \\ Ajuê Marica, Marica diga ajuê \\ Ajuê Marica, gonga. \\ (MORENO, 1958, p. 158)
}

Há a afirmação da individualidade do trovador, "Enoque afamado", ou seja, que era conhecido de todos. Era o sujeito que "não tem cirimonha", palavra que parece se tratar de mais uma variação coloquial, dessa vez para o termo "cerimônia", e não se sentia constrangido com a opinião contrária ao uso da maconha, como sugere "Minha cara é sem vergonha". Enoque ainda manifesta outra opinião, considerando a erva um substituto do álcool, menos nociva então que este. Por fim, as expressões "Ajuê" e "gonga" são similares a algumas expressões do kimbundu como a locução "aiê", a interjeição "aiuê" e o substantivo "ngônga”. (ASSIS JÚNIOR, 1947)

Mário Ypiranga Monteiro ouviu de um agricultor a seguinte quadra em Lago Cururu, Amazonas, no começo da década de 1960:

Dirijo é coisa incelente Remédio de dor de dente Assim como Deus não mente Dirijo não mata a gente. (MONTEIRO, 1966, p. 297) 
Dessa vez os versos afirmam as qualidades medicinais da erva, no Amazonas mais conhecida como "dirijo", sendo usada como "remédio de dor de dente". Esse foi, inclusive, um aspecto da planta reconhecido pelos próprios especialistas do proibicionismo, a exemplo de Assis Iglésias (1958, p. 21), um dos primeiros: "Certos indivíduos empregam a diamba como medicamento, em forma de chá". O usuário ainda afirma que o "dirijo não mata a gente", ou seja, maconha não causa "overdose", para utilizar um termo atual, o que considerava uma verdade inabalável (“Assim como Deus não mente”).

Outro folclorista que registrou as "loas da maconha" foi Alceu Maynard Araújo na década de 1950. Em viagem a Piaçabuçu, interior de Alagoas, ele anotou os seguintes versos, mantendo na grafia as palavras como teriam sido pronunciadas:

\author{
Marica, eu vi uma jóia perdida, \\ Dois mariante a caçá, \\ Três embarcação no má \\ Quatro poeta na lida \\ Cinco vapô de saída, \\ Pá carregá seis princesa, \\ São sete mulé de nobreza, \\ Cunversa com oito dotô, \\ São nove governadô, \\ e deis capitá de riqueza. \\ (ARAÚJO, 1979, p. 261)
}

Nessa composição o sujeito pode estar demonstrando, entre outras coisas, uma aguçada percepção da dimensão política na sociedade em que vivia.

Pode-se arriscar que quando diz "seis princesa" esteja se referindo a moças das elites econômicas locais, acompanhadas de mais alguém, provavelmente sua mãe, pois são "sete mulé de nobreza". Estariam elas conversando com "oito dotô" que são "nove governadô" e possuem "capitá de riqueza". Ora, ele não 
desconhece que, naquele contexto, ser "doutor" era uma das portas de entrada na vida política. Por isso as elites econômicas, que têm capital e riqueza, mandavam seus filhos estudar nas universidades das capitais: está se falando de oito jovens e seu padrinho político, talvez um coronel, o nono governador da história. Portanto, entre baforadas na "marica" cheia de maconha, nosso trovador discute as estratégias de alianças políticas das elites econômicas locais, nesse caso através do matrimônio entre seus descendentes, bem como, de formação dos seus quadros e dos mecanismos do apadrinhamento político.

Outras poderiam abordar as qualidades específicas de cada tipo de maconha, como essas provenientes do Maranhão:

\author{
Dizô, cabra ou cabrito \\ $\mathrm{Na}$ casa da tia Chica \\ Tem carne não tem farinha \\ Quando não é tia Chica \\ Então é a tia Rosa \\ Quanto mais véia mais seboza, \\ Quanto mais nova mais cheroza. \\ - Cheroza, mano, cheroza? \\ Dizô, dizô! \\ (IGLÉSIAS, 1958, p. 19)
}

Aqui os trocadilhos com a figura feminina e com alimentos são evidentes e merecem uma atenção maior que pode nos ajudar a solucionar a charada.

Assim como na visão dos proibicionistas, porém, com significados distintos, no "folclore da maconha" a mulher também ocupa um lugar paradoxal: ao mesmo tempo em que se preferia consumir as flores da "planta fêmea", por possuir efeitos mais fortes, acreditava-se que mulheres não deveriam participar da colheita, uma cuidadosa operação na qual não se dizia obscenidades nem se assoviava, nem mesmo andar pela plantação 
"sob ocasião das regras" sob pena de "machear" todas as plantas, ou seja, transformar todas na "planta macho", resultando num fumo não apreciado. ${ }^{33}$ Mas era a figura feminina que era usada para designar a erva, para o bem, como a protetora "mamãe Daruanda" em Salvador, e para o mal, como evidencia o frequente título de "maldita".

Assim, "tia Chica" e "tia Rosa" podem estar designando variedades da planta fêmea, sobretudo, quando se nota que a expressão "manga rosa” (HENMAN, 1986, p. 107) é empregada no universo do seu uso popular para se referir a uma qualidade de maconha, assim como "Rosa Maria". (PARREIRAS, 1958, p. 280) Nota-se ainda, nessa esteira, a referência ao processo de preparação da planta para o fumo, que deveria obedecer às regras para a colheita e a curtimenta, onde "seboza" e "cheroza" se referem à maturidade da planta consumida, se colhida mais velha e resinosa ou mais nova com odor mais forte. ${ }^{34}$

Outro ponto é a referência a alimentos como a "carne" e a "farinha". A alimentação era um aspecto importante no consumo da maconha, segundo os especialistas. Diversos estudos mencionavam a fome como um dos efeitos fisiológicos universais da maconha. São comuns termos como "camarão" para designar as inflorescências fumadas da planta e "manga rosa" para designar inflorescências bem desenvolvidas e amadurecidas, o que significava um fumo bom e muito apreciado entre

33 Sobre isso ainda nos diz Rodrigues Dória (1958, p. 3), evidenciando outras conexões históricas da prática: "Essa lenda a respeito da mulher menstruada é bem velha, e já Plínio, o Antigo, dizia que tão violenta era a toxicidade do sangue menstrual que seu contato, ou mesmo o seu vapor, podia azedar o vinho, tornar estéreis as sementes [...] e diversas coisas mais". A crença em poderes sobrenaturais da menstruação também era compartilhada pelas classes subalternas no Brasil colonial. (SOUZA, 1986)

34 Segundo Anthony Henman (1986, p. 107), em seu estudo sobre o consumo de maconha entre os indios tenetehara: "Distingue-se imediatamente um fumo bem curtido pela cor parda e pela ausência do cheiro de clorofila, característica da maconha em estado verde". 
os "diambistas" em oposição ao "pelo de macaco" ou "poeira", um fumo ruim, ressecado e com muitos materiais indesejados na sua composição. (CAVALCANTI, 1998) Assim, "carne" e "farinha" podem estar designando a qualidade da maconha a ser fumada. A maconha boa de fumar, então, era "tia Chica" ("tem carne não tem farinha"), mas podia também ser a "tia Rosa", uma "véia seboza" ou uma "nova cheroza", ou seja, mais ou menos curtida. "Dizô, mano, Dizô? Dizô!".

Por fim, Moreno (1958, p. 158-159) nos apresenta mais alguns desses versos colhidos em Propriá:

\author{
Inchaço grande é postema \\ Pano quadrado é lenço \\ Miolo de ovo é gema \\ Moça que dorme só \\ Vive numa tentação \\ Moça solteira é um cão \\ Pé de boi é mocotó \\ $[\ldots]$ \\ Me dero banho n'um taxo \\ A parteira disse sorrindo: \\ - Comadre este bicho é macho \\ - Maricas se o fio é macho \\ Banho sempre num taxo \\ Maricas o nosso fio é macho \\ E trouxe o nome de Patacho.
}

A primeira estrofe trata de uma série de assuntos da vida cotidiana popular, como esses definiam seus conceitos, tais como um "inchaço grande" ou "miolo de ovo" além de manifestar elementos do imaginário popular sobre a sexualidade feminina. A segunda estrofe parece tratar, de forma cifrada, da própria maconha. A "parteira" e a "comadre" da história conversam sobre um "bicho macho". Se lembrarmos da crença popular que afirmava o poder da mulher de "machear" a planta, 
caso entrasse em contato com ela, é possível supor que esses versos podem estar fazendo referência ao tipo do fumo. E sendo planta "macho", tipo de sabor não apreciado, como já vimos, a solução é fumar na "maricas" com água ("Banho sempre num taxo").

Os desafios dos "diambistas", entrecortados por baforadas no cachimbo, animando a reunião, "cheios de associações por consonância e ricos de definições", pareceram, acertadamente, aos olhos do diretor do Serviço de Assistência a Psicopatas de Sergipe, dr. Garcia Moreno (1958, p. 158), "uma pequena enciclopédia popular".

A prática das "trovas" nos "clubes de diambistas" guarda semelhanças inegáveis com outras práticas no Brasil, a exemplo do repente, da embolada, do candombe e do jongo. Em todas, o duelo de palavras, embalado ou não por acompanhamento musical, era - e ainda é nas que permanecem ativas - um código cifrado, no qual essas palavras podem dizer outras coisas para além do que a semântica imediata permite supor e, juntamente com os gestos e comportamentos da prática, reorganizam as fronteiras da percepção das identidades. (AGOSTINI, 2002; AYALA, 1999; SUASSUNA et al., 1997; TRAVASSOS, 2010)

Precisava ser iniciado para conhecer os códigos dos "diambistas". Assim como o jovem Inácio do conto de Alberto Deodato era preciso comungar de comportamentos e compartilhar valores comuns ao grupo. O dr. Assis Iglésias, ao perguntar a um dos "diambistas" de um "clube" do Vale do Mearim no Maranhão, em 1918, o que significava "Dizô" e receber como resposta que a expressão era "sutaque de gente doida", concluiu que aqueles "caboclos", que o dr. Leonardo Pereira considerou depois "idiotas" e "de uma indolência fantástica", empregavam o termo sem conhecer seu sentido, "sim" em "africano". Porém, 
ele é quem não conhecia dos sentidos, não era "gente doida", então não podia conhecer de seu "sutaque", ele foi quem não entendeu a piada. E não entender a piada pode ser o primeiro sinal de que se está diante de outro mundo. (DARNTON, 1986)

O duelo de palavras em ocasiões de uso da maconha não deve ter sido um fenômeno restrito às áreas do sertão, no interior dos estados, contudo, não foram encontradas informações recorrentes sobre a prática nas capitais, ocorrendo mesmo um silêncio sobre esse ponto. Sabe-se apenas que na Maceió de fins dos anos 1940 as autoridades se referiam à fumantes da erva encobertos "até o pescoço com areia [na praia] e no escuro da noite", formando "pirilampos" com a luz dos seus cigarros a queimar, "no entrechoques de ditos e desafios", mas não se sabe quem eram ou onde teriam aprendido a prática. (PARREIRAS, 1958, p. 274)

Em Salvador no período, assim como não foram encontradas referências ao uso da "maricas" nos casos policiais ou nos casos relatados pelos jornais, também não foi constatada a presença dos duelos de palavras. O que não quer dizer que não existia entre as rodas de fumo eventualmente ou que fosse um costume de todo desconhecido. Entretanto, uma ficha de inquérito organizada em 1943 pelo dr. João Mendonça, membro da Comissão Estadual de Fiscalização de Entorpecentes da Bahia, questionava ao "maconheiro" detido, entre outras coisas, "Como usa?", "Usa só ou em companhia?" e solicitava dos mesmos "Cite provérbios, versos, anedotas, modinhas sobre a maconha”. (FARIAS, 1958, p. 106-107)

Essa ficha de inquérito visava colher dos usuários detalhadas informações sobre o uso da droga. Com se tem visto, o interesse sobre as práticas de produção, preparo e consumo, assim como a investigação dos contextos socioculturais onde 
esses usos se davam foi uma constante na produção dos cientistas que escreveram sobre o assunto desde a década de 1910.

Nesse quadro eles buscavam os elementos que deveriam confirmar as suas teses e justificar a necessidade da repressão. Era fundamental para as autoridades e especialistas conhecer esses cenários e comportamentos. Não deixaram, porém, de perceber que significados coletivos e experiências que ajudariam os usuários a lidarem com a repressão ao hábito estavam contidos naqueles "provérbios, versos, anedotas e modinhas". O interesse do dr. João Mendonça nos dá indícios disso. Parece que, na capital, nem as autoridades nem os usuários desconheciam a prática. Mas, infelizmente não foram encontradas nenhuma dessas fichas.

Especialistas e autoridades que construiam o proibicionismo da maconha descobriam que seu uso coletivo, fosse no sertão, no Vale do São Francisco, ou no meio urbano das cidades em crescimento, apresentava as condições favoráveis à manutenção do hábito. Os "clubes de diambistas" do Nordeste são exemplos de uso controlado, de uso não problemático de psicoativos, de uso socialmente integrado entre as camadas subalternas acusadas de abusarem da substância e com ela cometer crimes. Como foi anotado, as reuniões costumam ocorrer aos sábados, nesses lugares, "véspera do dia de descanso". Apesar das poucas informações, sabe-se que os "diambistas" eram trabalhadores, geralmente agricultores, pequenos comerciantes, feirantes e pescadores, as ocupações mais comuns naquelas localidades do interior.

O mesmo José Lucena que verificou uma "sintomatologia discreta" entre os seus observados no Hospital de Alienados do Recife na década de 1930 e não percebeu "sinais de enfraquecimento intelectual" nem "sintoma desagradável" diante da "supressão brusca da maconha" entre os mesmos, é quem - se 
apoiando em reflexões do médico L. Livet - dá pistas úteis para compreender algumas possiveis funções e significados do seu uso coletivo para os "maconheiros":

A intoxicação em comum representa até certo ponto uma média dos graus de intoxicação individual. Ao contrário o consumidor isolado pode ficar aquém da dose ótima ou excedê-la com graves riscos de ordem pessoal ou social. Outra razão consiste em que nas reuniões a alegria de um se propaga aos demais, as anedotas ou ditos espirituosos (ou que buscam ser) se sucedem, tudo contribui para criar a euforia buscada [...]. (LUCENA, 1958, p. 210-211)

O uso coletivo permitia a manutenção de um consumo seguro da substância, medida essa estabelecida com base nas diversas experiências individuais, diminuindo os riscos de tensões na relação entre usuários e não usuários. Desenvolvendo e fazendo circular, através da experiência em comum, sanções (valores e regras de conduta) e rituais (estilos de comportamento), ou seja, controles sociais informais, endógenos aos grupos, possibilitavam "a utilização de psicoativos segundo um determinado padrão". Dessa forma, produziam e compartilhavam conhecimentos sobre "os métodos de aquisição e consumo, a escolha do meio físico e social para o uso, as atividades associadas a ele e as maneiras de evitar e lidar com efeitos negativos". ${ }^{35}$

A sociabilidade, o contato entre as experiências dos usuários criava um referencial comum para o reconhecimento e a busca dos efeitos desejados, tornando o grupo um ecossistema

35 Análise apoiada nas observações e hipóteses de Howard Becker, Gilberto Velho, Edward MacRae e Julio Simões sobre o uso de maconha na contemporaneidade. Apesar de terem analisado o uso nas classes médias da sociedade urbana, é possível, dadas as necessárias adequações, se apropriar dos elementos fundamentais que levantaram para compreender as questões culturais implicadas na prática em outras classes sociais. (BECKER, 2009a; MACRAE; SIMÕES, 2000; VELHO, 1998) 
propício e estimulante para a experiência psicoativa. Por fim, o uso coletivo também compartilhava um repertório de estratégias de enfrentamento e negociação com os controles sociais formalizados e as justificativas para a permanência do consumo num contexto de criminalização e crescente condenação moral da prática. Não estava errado, então, Moreno (1958, p. 157) "[...] ao afirmar na década de 1940 que os 'maconheiros' de Sergipe, Alagoas, da Bahia e de todo lugar 'fumam a planta e dela sabem mil coisas".

Ao final dessa trajetória conturbada e inebriante sobram questões, dúvidas e nebulosidade. A Cannabis sativa L. é, sem dúvida, uma alegoria da própria relação conflituosa do ser humano com a natureza. De uso amplamente difundido na sociedade brasileira, ao longo de quatro séculos a maconha floresceu sem muita dificuldade no seu chão, encontrando condições mais duras de sobrevivência com o correr do século XX. Não parece que tenha diminuído drasticamente o entusiasmo em torno da planta, o que se ampliou foi o choque moral que a prática passava a produzir numa também crescente percepção social condenatória do seu uso.

A segunda metade da década de 1960 marcaria uma fase em que a acusação pública de se relacionar com a "maldita" deixaria de recair apenas sobre as "classes pobres e incultas", passando a ser associada aos jovens das classes médias e aos movimentos de contestação característicos do período, chamados genericamente de "contracultura". Esses deveriam tecer suas relações próprias, estabelecer seus códigos, seus ritos, atribuir os valores de sua visão de mundo e aprender com as experiências compartilhadas a enfrentar ou negociar com os controles sociais no mundo da "guerra às drogas".

Observando a prática do uso psicoativo da maconha, as técnicas nas várias etapas da produção, do preparo e do con- 
sumo, foi possivel perceber os possiveis significados que a preenchia. Significados esses construídos na dialética permanente entre diferentes culturas e transmitidos, através de diversos canais, num ecossistema ${ }^{36}$ sócio-histórico próprio: o uso coletivo.

A criminalização que condenou o consumo de maconha e teve como suporte a transformação de um hábito em doença, por um lado, assentou bases sobre a ideologia racista que reestruturou a sociedade brasileira após o fim do escravismo e, por outro, anexou o seu combate a projetos mais amplos de controle social. Esse processo consolidou a perspectiva homogeneizadora do "vício" e da degradação como únicas formas possiveis de relação com a substância psicoativa. Do ponto de vista dos especialistas e autoridades, o "maconheiro" era, por todos os componentes da sua vida, um criminoso, um suspeito, uma ameaça; deveria ser "excluído da vida em sociedade" e "desprezado pelos seus semelhantes".

O resultado do uso da "erva maldita" não poderia ser outro senão a "loucura", o "assassinato frio" e sem motivo. Tal imagem, que desconsidera a multiplicidade histórica dos usos da maconha, é extremamente explorada pela maior parte dos meios de comunicação, como visto, desde a década de 1950, o que se repete, de certa forma, na atualidade, justificando a necessidade da "guerra às drogas".

Ao mesmo tempo em que se intensificava a condenação e a repressão à maconha nos fins da década de 1950, Parreiras (1958, p. 252) percebeu um estranho paradoxo: "A diamba é ainda o ópio dos pobres, o qual talvez não seja, dentro em breve, tal sua crescente valorização”. Ao contabilizar que um quilo

36 O filósofo Félix Guattari (1990) pode contribuir de forma significativa para um estudo que visa a entender a centralidade de uma planta numa determinada prática cultural e sua influência para a formação de certa visão de mundo. 
de maconha era comprado a 100 cruzeiros em grosso e vendido a 9 mil cruzeiros no varejo, uma das maiores autoridades do proibicionismo, à época, assinalou o principal resultado da campanha que ajudava a desenvolver: a imediata hipertrofia dos lucros de um comércio clandestino criado após a sua criminalização.

Espero ter deixado claro como o uso de um psicoativo, a maconha, para além da ideia reducionista do "vício", foi capaz de construir conhecimentos e sociabilidades ao longo de distâncias temporais e geográficas, como o uso coletivo permitiu aos usuários, ao contrário do que afirmava o discurso proibicionista, manter práticas controladas de consumo e transmitir experiências para a sua convivência com a vida comunitária de um lado e do outro do Atlântico. 